\author{
К.Л. Борисов \\ (Великобритания, Лондон) \\ А.К. Шапошников \\ (Россия, Москва) \\ etymol@mail.ru
}

\title{
РУССКО-САНСКРИТСКИЕ ЭТИМОЛОГИЧЕСКИЕ ЭТЮДЫ
}

В статье сообщаются некоторые небезынтересные для русской этимологии результаты совместного лексикографического проекта К.Л. Борисова и А.К. Шапошникова [Русско-санскритский сравнительный словарь]. В процессе составления словаря, соавторы обнаружили много новых случаев санскритско-русских изоглосс, пропущенных или не получивших должного освещения компаративистами прошлого. Выявлены общие словообразовательные модели. Уточнены или пересмотрены этимологии некоторых русск. и санскр. слов. В некоторых случаях удалось реконструировать семантическую историю слов, наметить первичные значения и проследить эволюцию семантики. Эти этимологические этюды охватывают часть праславянского словника от $S$ до $\check{Z}$.

Ключевые слова: сопоставление, изоглосса, архетип, реконструкт, этимон, семантика, словообразование, алломорф, омофон, этимология.

Идея создания электронного и печатного сравнительно-сопоставительного словаря русского и санскрита была изначально выдвинута лондонским санскритологом К. Л. Борисовым как профессиональное научное предложение на актуальный общественный спрос [Борисов 2015]. В ноябре 2015 г. был согласован договор о коллективной работе по подготовке к изданию полного «Русско-санскритского сравнительного словаря». Работа ведётся с помощью специально созданной компьютерной программы, объединяющей в себе электронную базу данных и удобный интерфейс с возможностью удалённого доступа через интернет для ввода данных. На данный момент основной корпус словаря превышает 1370 словарных статей разного рейтинга.

Уникальной особенностью системы является встроенный модуль автоматической компоновки и форматирования словарных статей с использованием системы вёрстки ХеTеX, которая позволяет не только отображать всевозможные шрифты (гражданский кириллический, деванагари, ижица, греческий и т. п.), сложную 
диакритику и унифицированную транслитерацию, но и создавать уже готовый к печати макет словаря в формате pdf.

Шаблон словарной статьи настроен на доказательность лексических сопоставлений (соответствий), как известных в этимологической и компаративистской литературе последние двести лет, так и обнаруженных недавно, в т. ч. оригинальных авторских. Словарные статьи передают историко-диалектную вариативность русской и санскритской лексики, излагают данные исторической словообразовательной морфологии и этимологии, делают очевидным не просто внешнее сходство русских и санскритских слов, но и их гомогенность, единое происхождение.

В процессе составления словаря, соавторы обнаружили много новых случаев санскритско-русских изоглосс, пропущенных или не получивших должного освещения компаративистами прошлого. Выявлены общие словообразовательные модели - древнее наследие того языкового состояния, когда раннепраславянский и индоиранский праязыки сосуществовали в рамках одного языкового ареала в ситуации языкового союза [Шапошников 2016]. В некоторых случаях удалось реконструировать семантическую историю слов, наметить первичные значения и проследить эволюцию семантики. Уточнены или пересмотрены этимологии некоторых русск. и санскр. слов. Следующие этимологические этюды охватывают часть праславянского словника от $S$ до $\check{Z}$.

Русск. съно (праслав. *sěno) др.-инд. śayana- или санскр. śyāna

В русск. языке XI-XVII вв. изв. сущ. съно 'трава вообще; сено, корм для скота', прилаг. съньныли, съныли 'сенной'; съно отм. в словарях с 1704 г., сънной сарай — с 1762 г., сенной — с 1771 г.; влр. сено дополняется блр. сена и млр. сі́но тж. (констатируем корневой “ять”). Этимология не ясна [Etym. sl. stslav. 13: 805], но согласно бытующему мнению выводится из праслав. *sěno, закономерно возводимого к и.-е. *koi-(ә)no- 'трава' (Рokorny 610). Следует при этом заметить, что главным источником реконструированного и.-е. этимона некогда послужила др.-греч. глосса коıv̀̀, приведённая в словаре трудных и неясных слов Иси-

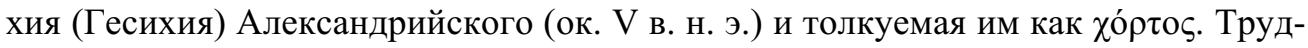

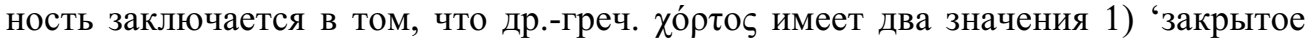
пространство, скотный двор, пастбище’ и 2) 'корм для скота, трава, сено’. При этом по мнению некоторых комментаторов словаря [Latte 1953], коıvò никоим образом не связано с травой, а является формой прилаг. коเv́ $\varsigma$ 'общий, совместный,

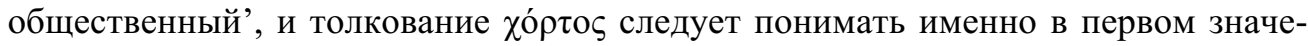
нии 'пастбище'. Таким образом, коı̀̀̀ следует переводить как 'общее (общинное)

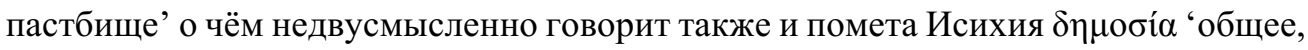
публичного пользования’ [Hesychius 1867: 892]. Эта неопределённость ставит под сомнение и.-е. архетип *koi-әnо- и является препятствием для однозначного отождествления его с праслав. *sěno, если только не связать его с корнем *kei- /*koi'лежать' [Pokorny 539-540] и допустить возможность семантического развития *koi-әno- 'то, на чем можно покоиться > трава > сено' только в балтославянском [см. напр. Pakerys 2002, Шапошников 2010: II, 315]. Следует отметить, что были 
попытки иного объяснения *sěno как производного от праслав. глаг. sěko ( *sěno < *sěkno) (Мельничук 1968).

Др.-инд. сущ. śayana-, śayanam 'a bed, couch, sleeping-place; the act of lying down or sleeping, rest, repose, sleep' производно от глаг. śí-, śéte, śayate, -ti 'to lie, lie down, rest' с широко употребительным адъективным суф. -na- (ср. причастие наст. времени śayāna м. ср., śayānā ж.) и возводится к и.-е. *kei- / *koi- 'лежать' [Pokorny 539540]. Др.-инд. материал косвенно поддерживает объяснение праслав. *sěno через и.-е. *koi- 'лежать', но не даёт однозначного решения.

Русск. сякать (праслав. *sękati) вед. siñcayati, secayati

В русск. словесности XI-XVII вв. изв. приставочные глаг. исслкати, преслкнвти, посАкнвти, осАкнвти, исслкнвти, выслкнвти [СлРЯ ХІ-ХVII вВ. Справ. Вып.]. В литературном языке закрепились глаг. сякнуть и иссякать, иссякнуть [Евгеньева IV, 328]. Русск. устар. ся́кнуть и обл. сяка́ть дополняются млр. сяка́ти 'фыркать, сморкаться'. Вост.-слав. примеры дополняются лит. sèkti, senkù 'опускаться', лтш. sīkt, sīkstu, sīku 'засыхать'. Восходит к праслав. *sękati, *sękajetb / *sęknoti, *sęknetb, глаг. многократного (-ati) и однократного (-nqti) вида от рефлекса и.-е. глаг. корня *sengw-: *senkw- 'to sink; засыхать', практически тождественного прагерм. глаг. *sinkwan, интенсивная огласовка *sakk-, coxранённому в англ. sink 'опускаться, оседать; топить; рыть' и швед. sacka 'to sink' [Pokorny 906; Watkins IER 75; Etym. sl. Stslav. 4: 246; 13: 813].

Вед. глаг. формы 3 л. ед. ч. siñcayati, secayati 'выливать, спускать, выделять, проливать, пропитывать или лить во что-л. или на что-л.; брызгать мелкими каплями' — каузативы глаг. sic-, siñcáti (вед. также sécate), продолжающие и.-е. глаг. корень *senkw- (с и без назальной инфиксации). Едва ли оправдана реконструкция и.-е. *sek- и попытка связать её с др.-инд. saścasi 'иссякаешь' (RV VIII, 51: Vāl. 3), как это сделано в словаре Дерксена [Derksen 450]. Значения др.-инд. sic-, siñc- и слав. *sęk- связаны именно с жидкостью и её истечением, что может говорить о том, что значение 'высыхать', традиционно реконструируемое для и.-е. глаг. корня *sengw-: *senkw-, на самом деле вторично: 'вытекать, истощаться' > 'терять влагу’ > 'высыхать'. К. Л. Борисов (вслед за В. Махеком) допускает возможность этимологической связи глаг. иссякать с сущ. сок, отмечая при этом трудности объяснения звуковых соответствий и переходов.

Русск. диал. сочить (праслав. *sočiti, *sočitb) вед. sácate

В русск. словесности XI-XVII вв. изв. сочити, соч8 'искать разыскивать', 'вести тяжбу', сочьба 'донос', а также приставочные производные насочити, осочити, отсочити. В САР V, кол. 666 отм. глаг. сочу’, сочи́шь, сочи́ть 'ловлю’. Влр. диал. сочить 'искать, отыскивать кого-, чего-л.' (пск., твер., нижегор., горьк., краснодар., курган., тюмен., тобол., сиб., иркут.), 'выслеживать, искать по следам (зверя)' (брян., смол., курск., перм., тюмен., тобол., Даль), 'ловить, хватать (вора, зверя)' (СА 1822: простонар., Даль), 'бить (рыбу)' (сев.-двин., твер.), 'говорить колкости кому-л., укорять, упрекать’ (Абхазия), ‘просить, канючить, выманивать что-л. 
обманом' (Даль) [СРНГ 40: 93]. Влр сочи́ть дополняется блр. сачьіць 'следить, присматривать за кем-, чем-л.' и млр. сочи́ти 'подкарауливать'. Восходит к праслав. *sočiti, глаг. на -iti от сущ. *sokъ 'преследование / преследователь, подглядывание / соглядатай, обвинение / обвинитель', восходящего к и.-е. *sekw-, *sokw'следовать, преследовать, видеть; показывать, направлять' [Pokorny 896; Etym. sl. stslav. 9: 530-531; 14: 854]. Ср. этимологию русск. сокол.

Вед. глаг. sac-, sácate, -ti 'принадлежать, быть присоединенным или верным чему-л.', 'служить, следовать, искать, преследовать, отдавать предпочтение, помогать' также продолжает и.-е. архетип *sekw-, *sokw-. Значения 'принадлежать, быть соединённым или знакомым с чем-л.; иметь что-л., иметь отношение; наслаждаться и т. п.' вероятно вызваны частичной контаминацией с глаг. sañj- (saj-), sajati 'липнуть, прикреплять' и вторичным семантическим развитием. Ср. семантическую эволюцию лит. sakýti, sakaũ и лтш. sacīt, saku 'говорить, сказать'; лат. sequor, secuutus sum, sequi 'идти вслед, следовать; провожать, следить; преследовать и т. д.', sequester, secundus, secus, socius; возможно и прагерм. глаг. *sehwan, гот. sailban 'to perceive, see; видеть' [Watkins IER 74].

Русск. сор (праслав. ${ }^{*}$ sorъ) санскр. (apa)skara 'нечистоты'

В русск. словесности XVI-XVII вв. изв. засорь 'мусор, отходы'; сущ. соръ отм. в словарях с 1704 г. В русск. диал. зафиксировано 7 гетерогенных омофонов сор и 3 омофона сора в разн. знач., включая и данный случай [СРНГ 40: 10-12]. Наи-

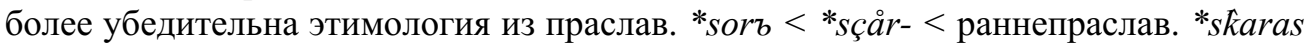
$<$ и.-е. $*_{s k-o} r$, *sk-n-, основы активного и инактивного класса [Pokorny 947, 1031; Watkins IER 78], регулярного производного с перегласовкой корня и окончанием -ъ от глаг. *sbrati, *sbrQ < *sçr- 'испражняться' (cp. *vorb — *vbrati), восходящего к и.-е. *[s]kr- : *[s]ker- : [s]kor- : *[s]k̄or- 'испражняться; excrement, dung'.

Др.-инд. apaskara- (*apa- + *skara-) 'нечистоты, отбросы' (с незакономерным отражением $s k$ ) дополняется авест. sairya- < *sçarya- < *skarias 'грязь' и восходит к и.-е. *[s]kr- : *[s]ker- : [s]kor- : *[s]kōr- 'испражняться' [Pokorny 947, 1031;

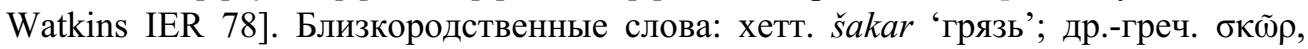
бкато́ 'кал, нечистоты'; др.-исл. skarn 'навоз, удобрение'.

Русск. сосна (праслав. *sosna) др.-инд. śiśná-

В русск. словесности XI-XVII вв. изв. сущ. сосъна и сосънь (1073 г.), прилаг. сосъновыи (с XII-XIII вв.) и сущ. сосъникъ 'сосновый лес' (с XIV-XV вв.); сущ. сосна отм. в словаре 1704 г., со́сна и сосна́ - в 1847 г., в словаре Даля, окончательно сосна́ - с 1940 г. [Ушаков IV, 399]; влр. диал. сосна, сосна дополняется блр. сосна и млр. сосна. Все предлагаемые до сих пор этимологии совершенно неубедительны [Грошева 2005: 250-275; Сердюкова 2008: 143-147; Etym. sl. stslav. 14: 857]. В случае др.-русск. сосъна (видимо, * сосьна) требует объяснения редуцированный -ъ- (паразитический звук?). Попытка выделить суф. -сна в этих словах наталкивается на трудности реконструкции (что есть корень со-?). Попытка усмотреть в праслав. *sosna основу с расширением -n- на базе и.-е. корня *kak-: 
kāk-: kank- ‘ветка', ‘колышек’ наталкивается на немотивированную палатализацию второго -k- (ожидалось бы слово *sokna), ср. этимологию сущ. сук и соха. Неубедительно выведение этого дендронима из и.-е. прилаг. *kasnos 'серый', ставшего распространенным вост.-и.-е. наименованием зайца.

Санскр. śiśná-, śiśnah м. р. и śiśnam cp. p. membrum virile, а также параллельный вариант śiśan (ср. др.-рус. сосъна), считаются производными от глаг. śnath-, śnathati 'пронзать, ударять, убивать', имеющего формы с удвоением типа аористов siśnáthat, aśiśnat, дезидератива śiśnathishati, сущ. śiśnátha 'прокалывание, пронизывание’ (ср. якобы тюркскую этимологию сущ. шиш). Эволюция семантики типическая: ср. соотношение праслав. *xujb < *skaujis и *xvoja < *skuoiā, лит. skùja и лтш. skujas мн. ч. 'хвоя', др.-ирл. scé < *skuilat- 'боярышник колючий'. В свете санскр. данных праслав. *sosna, наконец, получает типологически обоснованное и ясное словообразовательное толкование как основа с удвоением (so- < *çă- < *kə-) от корня *sna- < *çā- < *knō- без дентального расширителя основы, гомо-

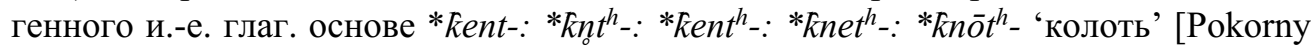
567]. При этом мотивация наименования сосны та же, что и у хвои — колючки. Однако нельзя полностью исключить и возможность праслав. адаптации цельнолексемного заимствования и фонетической адаптации из синдо-меотск. диал. Северного Причерноморья.

Русск. соха (праслав. *soxa) др.-инд. śākhā

В русск. словесности XI-XVII вв. изв. соха 'кол, подпорка, дубина, колодка, орудие пахоты' (с XV в.), 'мера площади, единица податного обложения в Русском государстве' (XIII-XVII вв.) [Срезневский III, 470]. Прилаг. сохатьй 'вилообразный’ отм. в словарях с 1794 г. Русск. соха́ 'примитивное земледельческое пахотное орудие', обл. 'толстая жердь, столб, подпора, подставка (обычно с развилкой на конце)', диал. соха́ 'жердь, бревно, столб как строительный материал’ (Р. Урал, каз.-некрас.), 'навес на столбах для хранения снопов соломы, сена и т. п.' (смол.), 'столб у колодца, на который крепится журавль' (ворон., сарат., орл., калуж., ряз., смол., иван., яросл., новг., чкал., новосиб.), 'толстая жердь, палка, кол, обычно с развилкой на конце, служащая подпоркой, которую подставляют к чему-л. или к ней привязывают что-л.; подпорка, развилок, подпирающий ограду' (астрах., дон., каз.-некрас., ворон., курск., тамб., орл., смол., Карелия, мурман.; олонецк. Куликовский; Шолохов), 'одна из расставленных в ряд жердей, на которых развешивают что-л. для просушки’ (костром., новг., селигер., пск., олон., Р. Урал), ‘деревянный кол с раздвоенным концом или острым железным крюком с одной стороны и привязанным канатом с другой, служащий якорем, который бросали на берег с плывущего по течению плота или баржи для причаливания или удержания их на одном месте' (смол., яросл., волог., волж.), 'посох’ (Р. Урал), а также 'мера земли’ (новг., Бурнашев) [СРНГ 40: 78-80] дополняются блр. саха́ 'соха, примитивное рало’ и млр. соха́ ‘подпорка'. Восходит к праслав. *soxa ‘сук с развилиной’, ‘кол’,

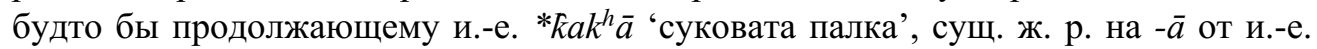
корня $k a k^{h}-, k a \bar{a} k^{h}$-, $k a n k^{h}$ - ‘ветка', ‘колышек' [Etym. sl. stslav. 11: 686-687; 14: 855]. 
При таком этимологизировании получаем уникальный пример рефлекса и.-е. $k^{h}$ в виде праслав. $x$. Альтернативная этимология праслав. *soxa из вост.-и.-е. *kaksā, варианта *koksā 'body part, hip, thigh', лат. сохa [Pokorny 611], приводит к регулярным фонетическим изменениям и умаляет достоверность вышеупомянутой этимологии. Изначальным мотивом номинации объекта, в последнем случае является суковатость палки, жерди, ствола с суком.

Др.-инд. śā $k h \bar{a}-, s^{\prime} \bar{a} k h \bar{a}$ и н.-перс. š $\bar{a} \chi$ 'ветвь, сук' также возводят к и.-е. *kak $k^{h} \bar{a}$

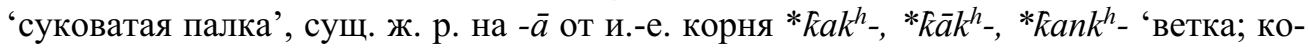
лышек’. Следует особо отметить совпадение в ж. роде. Ср. этимологию русск. сущ. сук, сохатыц̆, лит. šakà, šakẽlè, šakótas 'разветвлённый', лтш. saka 'ветвь, сук, развилина, разветвление дерева'; арм. çax 'ветка, рогатка', гот. hōha 'плуг’.

Русск. спорый (праслав. *sporz) др.-инд. sphirá

Изв. др.-русск. и цслав. спорь 'обильный'; влр. диал. cnópыĭ, cnop, cnopá, cnópo, диал. сnор 'хороший урожай, изобилие, способность давать хороший урожай' (смол., курск., петерб.), ‘выгода, прибыль, прибыльность' (волог., смол.), 'сноровка, ловкость' (ЭстССР), прилаг. спорый [СРНГ 40: 222; 235-236], дополняются млр. спо́рий 'быстрый, успешный; объемистый' и блр. спор 'успех, прибыль'. Восходит к праслав. *sporъ (уже антск. этноним $\Sigma \pi$ о́о у Прокопия Кесарийского), регулярному именному производному от плохо сохранившейся глаг. основы *sper-: *spěr[Топоров 1982: 145-157; Он же 2006: 283-296], восходящей к и.-е. прилаг. *sp(h)әroprosperus [Watkins IER 82], вероятно, расширению формантом -r- глаг. корня *sp $(h)$ $\bar{e}(i)$ - 'to thrive, prosper' [Watkins IER 82; Pokorny 983], ср. русск. глаг. сntmь, сnью.

Др.-инд. sphirá, sphārá, ‘тучный, обильный, богатый’ также выводят из и.-е. прилаг. *sp(h)aro- prosperus (нулевая огласовка корня), *sp(h)êro- (с продлённым вокализмом) и давно сопоставляют [Monier-Williams] с лит. прилаг. spérus 'быстрый, стремительный, спешный', лат. prosperus (из *pro-sparos) 'счастливый, благоприятный', др.-исл. sparr 'бережливый, пощаженный’; с финейск. основой *spart-, расширенной дентальным формантом, в составе "царских" имён собственных Spartakos, Spartokos, Spardokos и в арм. прилаг. p'art'am 'обильный'.

Русск. стена (праслав. *stěna) санскр. styāna-

В русск. языке XI-XVII вв. изв. стьна 'стена здания', 'ограда, загородка', 'оплот' и прилаг. стьньныи 'стенной'; сущ. стьна отм. в словарях с 1704 г., стьна' [CAP V, кол. 934-937]; влр. стена дополняется блр. сияна и млр. стіна тж. (констатируем корневой «ять»). Восходит к праслав. *stěna, возводимому к и.-е. *stāi-n'камень', 'твердь', производному (прич. прош. вр.) с суф. -n- от корня *stāi-: *sti'сжимать, уплотнять' [Pokorny 1010; Etym. sl. Stslav. 15].

Санскр. styāna-, styānam образовано от глагола styai-, styāyati (styāyate) 'собирать в кучу или в массу; твердеть, густеть, увеличиваться', который также можно

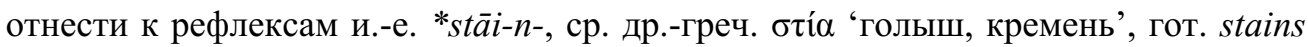
'камень'. Санскр. формы побуждают серьёзно задуматься над правильной реконструкцией праслав. архетипа: *st'ān $\bar{a}<*^{*} \operatorname{sie} n \bar{a}$ или *stāināa? 
Русск. студ (праслав. *studb) санскр. todá-

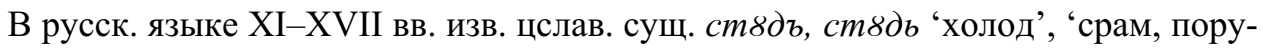
гание'; глаг. студить, стужу отм. в словарях с 1771 г., церк. студъ 'срам, поругание' (Даль); влр. диал. студа (арханг.), студь (сев.-вост.), студель (пск.), стылды (моск., ряз., ворон., тамб.), простуда дополняются блр. студзі́ць и млр. студити. Считается, что вместе с цслав., ст.-болг. стоудъ 'холод' и 'стыд, срам' (Супр., Остром.), русск. диал. студ восходит к праслав. *studb < *staudas, продолжающему и.е. диал. *[s]tud-, [s]tund- 'колоть; бить, колотить, ударять (гулко)' [Etym. sl. stslav. 15], ср. русск. глаг. тузить. Первичную семантику этого слова усматривали в вероятной связи студа с холодом через характерное покалывание на морозе. Мы бы обратили внимание на возможную звукоописательную составляющую первичного значения (на морозе предметы издают гулкие шумы при ударе), ср. преобладающую звукоизобразительную семантику и.-е. родственных слов: лит. stùmdytis

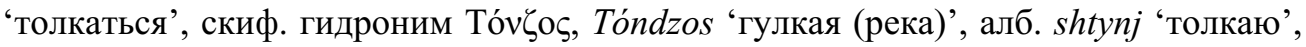
лат. tundo, tutudī, tū [n] sum, tundere 'бить, колотить, ударять', гот. stautan 'толкать' . Предполагаемая дальнейшая семантическая эволюция 'холод' > 'стыд’ типологически соответствует оппозиции мороз и мразь, мерзость. При этом есть и иная точка зрения на студ как оформление дентальным формантом и.-е. *steuðə-, *stāu-,

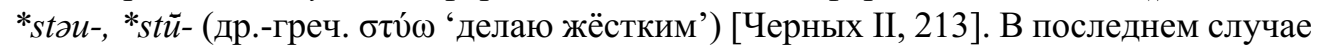
остаётся без объяснения суффиксация: $-d$ - или $-d^{h}-$ ? А семантика может быть мотивирована аналогичным развитием терпнуть $>$ оторопеть $>$ mpуn [Шапошников 2007: 431-435].

Санскр. todá-, todáh ‘тот, кто жалит; укол’ производно от глаг. tud-, tudáti ‘толкать, колоть, бить’ и восходит к и.-е. диал. сущ. *taudas по глаг. *[s]tud-, [s]tund'колоть; бить, колотить, ударять (гулко)' без подвижного $s$-. Эта санскр. этимология позволяет более решительно высказаться в пользу первой этимологии русск.

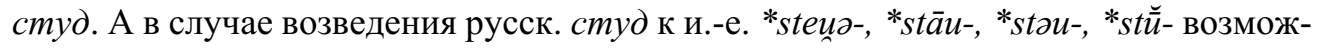
но родство с санскр. глаг. sthu- 'быть прочным, жёстким или сильным'. Неоднозначность этимологических решений понижает рейтинг сопоставления.

Русск. сука (праслав. *suka) санскр. śvaka

В русск. словесности XV-XVII вв. изв. сущ. с8ка и прилаг. с8чии; сущ. сука отм. в словарях 1762, 1771 гг.; влр. сука дополняется млр. сука. Восходит к праслав. *suka < *çaukā, производному с суф. $-k$ - от корня $*_{s u-}<* c ̧ a u-<* k e u-$, восходящего к тому же и.-е. корню, что и другое производное *ku-(u)ōn, *ku-nos 'пес, собака' [Pokorny 632; Watkins IER 46], только без расширителя основы -n-, ср. др.прусск. sunis, лит. šũ̃, šuñs 'собака', вост.-лит. šunis, лтш. suns, род. п. suņa, мн. ч.

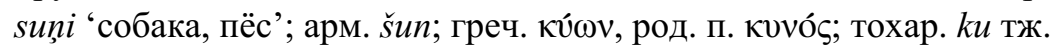

Др.-инд. çúvā, çvā, śvā, śvan, род. П. çúnas 'собака; dog, hound, cur' и śvaka'волк' вместе с авест. spā, род. п. sunō и др.-перс. spaka 'собака' очевидно образованы от некоего корня śva-, śu-, гомогенного и.-е. корню *kuūon, *kunos 'пес, собака' [Pokorny 632]. Более поздние формы (отмечены только в Махарабхарате Damayantīkathā) śvaka-, śvakah м. p. 'волк’ бесспорно однокоренные śvā, śvan, 
род. п. śúnas 'пес, собака'. Первичное значение и.-е. корня *ku(u)-: $k(u) e u$ - в основе *kuūon, *kunos может быть осторожно намечено как звукоизображение, подобно сова, совка. Семантическое развитие 'волк' или 'собака' не столь уж далеко разошедшееся, чтобы совершенно скрыть глубинную идею о семействе собачьих. Нет ничего типологически невозможного и в закреплении одной из форм именно за самкой собаки.

Русск. слой (праслав. *sъlojb) санскр. samlayá

В русск. словесности XI-XVII вв. изв. слои (XIV в.); сущ. слой отм. в словарях с 1771 г.; влр. слой, род. п. слоя дополняется млр. слій, род. п. слоя. Восходит к праслав. имени (результата) действия *sblojb, относительно позднему отглаг. производному с суф. -jъ с перегласовкой корня от приставочного глаг. *sbliti, *sblbjo, восходящего к и.-е. глаг. *li-: *lei-: *le--i 'лить, течь' [Pokorny 664; Watkins IER 47].

Санскр. samlayá 'settling or sitting down; melting away, dissolution; осаждение или усаживание вниз; расплавление, растворение' также является приставочным производным (sam-) отглагольным сущ., образованным с помощью вторичного суф. -(i)ya от глаг. lì-, lìyate (в Ригведе также lāyate) 'плотно прилегать, льнуть, липнуть', тесно связанным с глаг. корнем rī- (lì-), rìyate 'размягчаться, плавиться, течь, капать' (очевидно по линии семантического развития 'размягчаться, плавиться’ > ‘делаться липким'). Этот двойственный характер санскр. samlayá придаёт но-

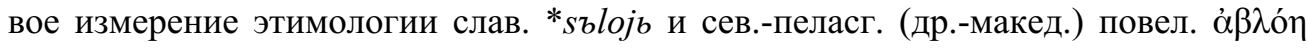
'возлей, соверши возлияние' [Шапошников 2009: 303-311].

Русск. смерть (праслав. *sъmьrtb) санскр. sumrtyu

В русск. словесности XI-XVII вв. изв. сущ. съмьрть, прилаг. съмьртьнь, съмьртьныл; сущ. смерть отм. в словарях с 1704 г., прил. смертелное отм. в словаре Берынды 1627 г., смертельный и смертный - с 1731 г.; влр. смерть дополняется блр. смерuьь. Восходит к праслав. *sъmbrtb (наряду с *mbrtb), формально конфиксации с преф. *sb- и суф. *-tь от основы глаг. *merti, *mbrQ 'помереть', восходящего к и.-е. *mer-: *mor-: *mr- ‘умирать' [Pokorny 735]. Есть разные подходы к объяснению начального $*_{s b-.}$ Одни выделяют глаг. прист. ${ }^{*} s b-$ и реконструируют позднее отглагольное имя, отвлеченное от приставочного глаг. *sbmerti, *sbmbrQ и оформленное суф. *-tb. Другие усматривают в праслав. *sbmbrtb пережиток и.-е. словосложения *su-mrtis 'благая смерть, т. е. своя, естественная' [Трубачёв 2002: 192-193, 423].

Санскр. mrti-, mrtih производно от др.-инд. глаг. mr-, mriyáte (также marati, или márate) с первичным субстантивным суф. -ti. Зафиксирован по меньшей мере один случай с прист. sam- - прилаг. причастного характера sammrta 'совсем мёртв'. Кроме того, этимология и.-е. словосложения *su-mrtis ‘благая смерть' обретает некоторую поддержку в виде санскр. sumrtyu 'лёгкая смерть' и sumrta (su-mrta) 'безжизненный, полностью мертвый’, образованных с помощью проклитики $s u$ - (sū-) 'хорошо, много, очень сильно'. Видимо, русск. и санскр. 'смерть - лёгкая смерь' действительно уходит корнями в вост.-и.-е. языковой ареал (или даже союз), ср. 
не разделяющие эту изоглоссу лит. mirtìs, mirties, лтш. mirte; лат. mors, mortis; гот. maurpr от прагерм. *murp- 'убийство' < и.-е. *mrt-is 'смерть'.

Русск. серебро (праслав. *sbrebró) санскр. śubhrám

В русск. словесности XI-XVII вв. изв. сьребро, серебро, позднее серебро отм. в словарях с 1771 г.; влр. серебро дополняется блр. серебро́ и млр. серебро́, срібло́. Этимология слова остаётся неясной [Etym. sl. stslav. 16: 935-936]. О.Н. Трубачёв возводил к праслав. *sbrebro < *çir'abran, издавна видоизмененному (вследствие высокочастотного употребления?) и.-е. диал. прилаг. $* k r b^{h} r o-$ предположительно, заимствованному из синдо-меотск. диал. [Трубачёв 1978: 99; Он же 1999: 274] с невыясненной и.-е. этимологией корня *kr $b^{h}$, варианта и.-е. *skerb(h)-: *skreb(h)'sharp, pointed object, a sow; pieces; to scratch, to scrape; scrabble; shrub; trench, ditch; embankment' [Pokorny 938; Watkins IER 78]. Первичное значение, возможно, исходит из 'делать насечки острым предметом, украшать резьбой’?

Вед. прилаг. śubhrá- 'красивый, светлый, блестящий', санскр. сущ. śubhrám ср. p. ‘серебро’ (только в некоторых средневековых санскр. словарях), образовано от глаг. корня śubh-, śubháyati 'украшать' с первичным адъективным суф. -rá. Авест. не имеет аналога, но др.-инд. слово дополняется синдо-меотск. гидронимом $\Sigma ı$ рлх́л $\alpha$ (Sibriápa) 'серебряная река', однокоренным гидронимом из Ликии

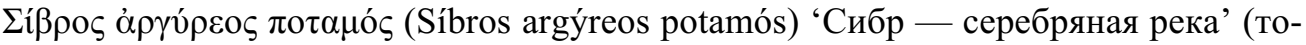
понимическое наследие скиф. походов в Азию?). В обоих случаях корневой слогообразующий сонант $r$ был утрачен в глубокой древности и замещен краткими узкими гласными $u$, $i$, тем не менее, архетип этих форм, безусловно *śr $r b^{h} r a-<$ *kr $b^{h} r o-$ Примечательны прочие рефлексы этой адъективной основы: др.-прусск. sirablan, лит. sidrabras, sidãbras, лтш. sidrabs, sudarbs 'серебро' (для прабалт. языка реконструируются прототипы *sirablan *si $[d]$ rabras, заимствованные из какого-то другого сатемного языка); арм. surb 'чистый, святой' является результатом метатезы в *çubr - возможное заимствование из индоиранских диал. Сев. Сирии; гот. silubr, др.-исл. silfr, др.-англ. seolfor, др.-в.-нем. silabar 'серебро' все из прагерм. *silbr-, скорее всего, раннего заимствования из предковых видов бал-

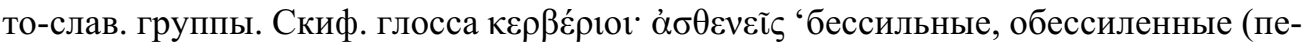

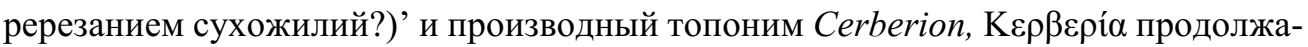
ют архетип *kr $b^{h}$ rio- без ожидаемой палатализации, если они вообще относятся к этому случаю.

Русск. вапа (праслав. *vapa) др.-инд. vāpi

В русск.-цслав. словесности XI-XVII вв. изв. сущ. вапа, вапь и лвже или езера 'мелкий залив; водоем со стоячей водой' (Шестоднев Ио. екз., 69. 1263 г.), вода смердъщиа въ вапъ (Жит. Пафн. Мин. февр., 279.). Из цслав. (ст.-болг.) вапа (Супр. или Ретков сб. XI в.) [СлРЯ XI-XVII вв. 2: 16-17], продолжающего праслав. основу на $-\bar{a} *^{*} v a p a<* u \bar{a} p \bar{a}$, неуверенно возводимую к и.-е. $\breve{\bar{a}} p$ - 'вода' [Pokorny 51-52], этимологически неясную [Etym. sl. stslav. 17: 1038]. Начальное v- можно объяснить как паразитический протетический глайд (в праслав. обычно $j$ - или $v$ - перед 
словом, начинающимся на $a$-), ср. подобную протезу в праслав. *atra - русск. ватра, ватрушка. В таком случае, др.-инд. корень ар 'вода' в apsaras, apam napat является правильным соответствием слав. вапа. Заметно отличие в долготе корневого гласного.

Корневой гласный $u$, особенно в адъективной основе на -i $\bar{a}$, -io- отмечается в палеобалканской гидронимии (Axiopē, Axiupa Черна Вода) и в др.-прусск. жируап 'облако', лит. ѝре 'река', лтш. ире 'ручей, река'. Возможно, перед нами древние и.-е. синонимичные алломорфы *ap- и *up- с неясной для нас теперь апофонией. В таком случае этимологическое возведение к корню *иер- 'бросать, выбрасывать' [Pokorny 1149] излишне. Гипотетическое первичное значение 'выкопанный или образованный дамбой водоём' не имеет достоверной мотивации.

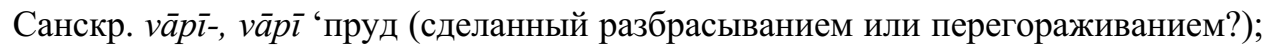
большой округлый водный резервуар, озеро, бассейн' толковали как производное с суф. имени действия (почти всегда ж. р.) -i (неясна, однако, природа долготы этого l) от вед. глаг. vap-, vápati, -te (перф. формы uvāpa, ūpúh; ūpe) 'разбрасывать, раскидывать; сваливать в кучу, перегораживать дамбой', возводимого к и.-е. глаг. *uер'бросать, выбрасывать' [Рokorny 1149]. Неубедительное толкование ввиду другого производного от этого же глагола др.-инд. сущ. ж. р. vapä-, vapä 'муравейник (куча земли, насыпанная муравьями)', 'углубление, полость, дыра', которое контрастирует с праслав. *vapa и в степени корневой огласовки, и в семантике. Настораживает и отсутствие какой бы то ни было "рукотворной" семантики у палеобалканских гидронимов с -ара, -ира в составе, и у рефлексов в балтийских языках. Невысокий рейтинг сопоставления отражает неясность этимологии и слав. и санскр. слов.

Русск. варити, варяти санскр. várati, vāráyati

Изв. ст.-русск. варнти 'быть вначале, предварить, предупредить, предуведомить, опередить, дождаться, подстеречь', варгати 'предварять, предупреждать' [СлРЯ XI-XVII вв. 2: 219], позже варяти, варять, варяю, варяет несврш. 'упреждать кого в каком месте; ускорять прийти куда-л.; идти куда-н. перед кого-л.; предварять' (САР I, 509; Трд. Древн. Рос. 212) [СлРЯ XVIII в. 2: 218], церк. и стар. варить 'упреждать, опережать; предварять, предостерегать, оберегать' [Даль I, 166]; в совр. литер. языке устоялись только приставочные производные предваpúmb 'предупредить, опередить' и предваря́mь 'предупреждать, опережать, предшествовать'. Принято считать заимствованиями из цслав., ст.-болг. варити, варяти, пръдварити, пръдварьти (Etym. sl. stslav. 17: 1038), рефлексов праслав. *variti, *var'Q, *var'ati, *var'ajo. Первичное значение глаг.: 'внезапно появиться и застать на месте (преступления), подкараулить’ хорошо сохранилось в болгарском однокоренном лексическом гнезде (заваря, изпреваря, варарин), вторичные значения 'охранять, ограничивать, защищать' и 'упреждать, предостерегать' развились позднее. Весьма вероятно бытование позднепраслав. парадигматических вариантов глаг. *váriti, *váritb и *var'áti, *var’ájetb, продолжающих раннепраслав. основу *uār(i)at'ai, *uār(i)aiati (3 л. ед. ч.), этимология которой становится понятнее при сопоставлении с др.-инд. материалом. 
Вероятно, эта же основа представлена в др.-инд., вед., санскр. глаг. формах várati, várate (неопред. varitum, varītum) 'to cover, screen, veil, conceal, hide, surround, obstruct' (RV), 'to close (a door)' (AitBr), 'to ward off, check, keep back, prevent, hinder, restrain' (RV, AV); страд. vriyate (aop. ávāri) 'to be covered or surrounded or obstructed or hindered' (RV, MBh), кауз. vāráyati, -te (страд. vāryate) (MBh) 'to cover, conceal, hide, keep back, hold captive' (RV), 'to stop, check, restrain, suppress, hinder, prevent from' (MBh), 'to exclude' (Siddh.), 'to prohibit, forbid' (MBh), 'to withhold' [MonierWilliams] дополняется др.-перс. pari-vāraka 'protective’. К этой и.-е. глаг. основе относили лат. прист. глаг. operire 'to cover' и aperiri 'to open, uncover' (*op-/*apo+ uerit'i), гот. warjan, нем. wehren, Wehr, англ. weir. И.-е. архетип *uer- 5, *uor-, *uor-o- 'to cover' [Pokorny 1160].

Русск. вёдро (праслав. *vedro) санскр. vidhra-, vidhram

В русск. словесности XI-XVII вв. изв. ведро 'ясная солнечная погода, зной, засуха' [СлРЯ XI-XVII вв. 2: 49], цслав. ведръ 'ясный', ведро ‘вёдро’; влр. вёдро дополняется млр. ве́дро 'ясная погода'. Из праслав. *vedro, *vedrz, *vedra 'ясная погода', субстантивированного прилаг. трёх окончаний. Одни этимологи предполагали прямое заимствование из прагерм. (*weðr-) или дочерних германских яз. [Schmidt 1889; Мартынов 1963; Etym. sl. stslav. 17: 1040-1041]. При этом само прагерм. слово не представляется этимологически прозрачным: некоторые полагали прагерм. *weðro- производным с суф. -ðro- от глаг. *we-- 'to blow' [Watkins IER 95], который прежде реконструировали как *au(e)10 [Pokorny 81]. Другими предлагалось объяснение через и.-е. корень *ued-, тот же, что и в праслав. *voda, с другой степенью чередования, но без внятного объяснения семантической связи воды с ясной погодой; при этом ссылались на сущ. *vydra, но с объяснением -r- в *vedro, как суф., аналогичного *bodrъ и * rudrъ [Черных II, 137]. Предполагаемая связь слова с и.-е. предлогом $a u$ - (aue); $u \bar{e}$ - 'от, прочь' осложняется тем, что в праслав. он дал предлог $u$ и приставку $u$ - <*au-, фонологически вероятнее связь с и.-е. й раздваивать'; в обоих случаях значение второго элемента -dro- остаётся неясным. Скорее всего, перед нами производное с адъективным суф. -r- от корня несохранившегося глаг. *ved-, *věd- или даже *bd-/*ěd- (если $v$ - $(n-, j$-) протеза или остаток более сложного анлаута *gu-?), который соблазнительно отождествить с плохо сохранившейся в праслав. лексиконе (*ěstěja, *věstěja, *něstbje) и.-е. основой *aidh-, *idh- 'гореть, жечь', расширенного и.-е. корня *ai-3 'to burn' [Pokorny 10; Watkins IER 1]. Родственные слова: др.-макед. $\alpha \delta \rho \alpha \tau \alpha, ~ \alpha ่ i \delta \rho \alpha \tilde{\alpha} \alpha \alpha i \theta \rho i ́ \alpha$ 'ясная, солнечная погода' < *aidhr- или *uidhr-ai- [Pudić 1971: 207-223; Шапошников 2009: 303-311]. Сюда же, вероятно, и лит. giẽdras óras 'ясная погода', лтш. dzidras debesis 'ясное, безоблачное небо’ также с неясной природой анлаута.

Вед. прилаг. vìdhra-, vìdhram (трёх родов) 'чистый, прозрачный, ясный; clean, clear, pure', сущ. ср. p. (только в мест. п.) 'чистое небо, солнечный свет; clear sky, sunshine', 'ветер; wind', 'огонь; fire', которое также не имеет достоверной этимологии, чаще всего игнорировалось европейскими этимологами. Предлагаемое древними инд. лексикологами [Uṇādisūtra ii, 26] толкование как сложение vi- и indhra-, 
образованного с суф. -ra- от вед. глаг. indh-, inddhé, ìdhé 'быть зажжённым; гореть, пламенеть' поддерживается в сл. Mayrhofer'a. Пожалуй, следует принять словообразовательную модель с адъективным суф. -ra- от основы vildh-, требующей дальнейших этимологических изысканий (какова природа этого $v$-: протеза или рефлекс и.-е. й̆- 'отделять, раздваивать'?). Др.-инд. словообразовательная модель оказывается, в таком случае, аналогичной европейским моделям: сев.-пеласг. (др.макед.) $\alpha 1 \delta \rho \alpha \tau \alpha$ 'ясная, солнечная погода', юж.-пеласг. (эллин.?) $\alpha i \theta \rho i ́ \alpha$ 'ясная, солнечная погода’, прагерм. *weðr-, праслав. *vedro.

Русск. верешь, вершь (праслав. *veř̌s, *vbř̌b) др.-инд. vrās

В русск. словесности XI-XVII вв. изв. др.-русск. сущ. вьршь, вьрьшь, верешь ‘хлеб, жито' [СДРЯ XI-XIV вв. 2: 270: примеры из рукописей XII-XIII-XIV вв.], ‘яровое (злаки ярового посева)' (1127, 1230, 1468 г.), ‘хлеб, жито, зерно’ (XVXVI вв.) [СлРЯ XI-XVII вв. 3: 87, 109-110], влр. диал. верешь, вершь, верши 'хлеб, жито в складах; клад, стог, скирд; яровые посевы' (валд.), 'хлеб в копнах, скирдах, зерно’ (пск. 1462-1471 гг.) [Даль I, 184; СРНГ 4: 178; ПОС 3: 110], позднее слово выходит из употребления и не включается в толковые словари. Из праслав. *vbršb *veřs ‘ 'кладь хлеба, скирд’. Согласно некоторым этимологам, праслав. *vbršb является производным от праслав. глаг. *verxt'i, *vbrxo (цслав. врғuтu, вьрхв, ст.болг. връщци, връхқ) 'молотить', *vbršiti ‘вытаптывать снопы скотиной', как и производное с перегласовкой корня *vorxъ, ср. русск. ворох и болг. врах 'ток, снопы, предназначенные для обмолота'. Но эти глаголы демонстрируют позднее семантическое развитие, не подсказывают первичную семантику и мотивацию всей этой однокоренной группы. Первоисточник: и.-е. основа, составленная из корня *uеr'крутить, вращать' [Pokorny 1169-1170] и расширителя основы -s-, с первичным значением 'свертывать, переворачивать, перетаскивать, накладывать кучей (срезанное?)', в то время как и.-е. *uers- 'тащить по земле; to confuse, mix up' [Pokorny 1169; Etym. sl. stslav. 18: 1089]. Производные в различных и.-е. языках, формально возводимые к и.-е. основе *uer-s-, выступают практически как омофоны со значениями 1) 'мести, тащить, наваливать кучей': праслав. *vbršiti, русск. ворох, лтш. vārsms 'хлеб, разостланный для обмолота', хетт. *uarš- 'жать, собирать урожай, тереть', лат. verrō ‘мету, сметаю в кучу' (*rr<*rs) и 2) ‘высота, верх, подъём’: русск. верx, навершие, лит. viršùs, лтш. virsus 'верх', хетт. *uarš-tta-, *uaršíe, -a 'поднимать, собраться, собраться с силами' [Kloekhorst 2008: 969-971], лат. verrūca 'возвышение, бородавка'; др.-инд. varșmán-, varșmá 'высота, верх' .

Вед. сущ. vrā- 'куча, толпа, множество' чаще употреблялось во мн. ч. vrās (vrāh) и его морфология остаётся неясной. Можно предположить, что оно продолжает и.-е. *uer-(s)- со знач. 'накладывать кучей (срезанное)' или *uer-(s)- 'тащить по земле; to confuse, mix up'. Такое последовательное и системное соответствие может говорить о возможном глубинном единстве ('собирать в кучу' > 'делать высоким’?). Огласовка корней, расширитель основы и неясность этимологии слов вынуждают присвоить сопоставлению невысокий рейтинг. Родственные слова: лтш. vārsms 'хлеб, разостланный для обмолота; груда провеянного зерна'; хетт. 
*uarš- 'жать, собирать урожай, тереть' и uarši (о с/х работах)'; лат. verro, verrere < *versō, *verset'i 'волоку, волочить; мету, мести'. Ср. верх, вершие.

Русск. весёльй (праслав. *veselъ) др.-инд. vasula

В русск. словесности XI-XVII вв. изв. прилаг. весель, весельи, невесельи, превесельи [СлРЯ XI-XVII вв. 2: 112]; влр. ве́сел, весела́, ве́село, весёльий дополняется блр. вясёль и млр. весе́лий. Согласно широко распространенному мнению, восходит к праслав. *veselb(jb), -a(ja), -о(je), производному прилаг. с суф. -el- (ср. тяжёльй) от несохранившейся в чистом виде основы *ves- 'добрый, благой, хороший'. Предполагаемый первоисточник: и.-е. прилаг. *su-, *uesu- 'хороший, добрый, благой’ [Pokorny 1174; Etym. sl. stslav. 17: 1045], ср. гот. глаг. wisan 'радоваться'. Неудовлетворительно подходят семантически и другие и.-е. архетипы *uеs-1 'to live, dwell, pass the night' [Pokorny 1170], *ues-2 'to eat, consume' [Idem 1171], *ues-3 'wet, ooze' [Idem 1171], *ues-5 'to clothe' [Idem 1172], *ues-8 'to buy, sell' [Idem 1173], *ues- 'evening, night' [Pokorny 1173; Watkins IER 101]. Вышеупомянутые этимологии не помогают реконструировать семантическую эволюцию слова и не дают категорического ответа на вопрос о происхождении интервокального -s-, который может восходить в данном случае и к и.-е. -su- (**uesuelos?), и к -ps-, -sp-, $-t s-,-k s-,-s k-$, и даже к палатальному $-k-$. Поэтому, вполне возможно и другое толкование прилаг. *veselb, как сложения приставки *ve-, означающей ту или иную чрезмерность, как недостаток (ср. и.-е. приставка удаления, снижения *uе-), и некой основы *sel-<*kel- со знач. 'народное гулянье', родственной лат. cel- в celeber 'оживленный, многолюдный, торжественный, пышно справляемый', celebrare 'справлять торжества, праздновать при большом стечении народа'. Ср. аналогичную этимологию сущ. вечер. Некоторые полагали, что из праслав. заимствованы в др.-прусск. wessals 'веселый' и лтш. vesels 'здоровый' [Черных I, 145]. Но это могут быть исконно родственные слова: др.-прус. wessals 'веселый', лтш. vesels 'здоровый, целый, невредимый'; иллир. (агафирск.?) глоссированное имя собств. Veselia Felicetas в римской Далмации II в.

Санскр. прилаг. vasura 'valuable, rich' и сущ. vasula 'god' на элементарном уровне может быть связано с корнем vas 'shine, grow bright', но, вероятнее, с др.-инд. $s u$-, vásu 'хороший, добрый, благосклонный', которое дополняется авест. vayhu-, vohu 'good'. Невысокий рейтинг сопоставления обусловлен неясностью этимологии как русск., так и санскр. слов.

Русск. въсъ (праслав. *věsъ) санскр. vīça

В русск. словесности XI-XVII вв. изв. сущ. вьсъ 'вес, тяжесть'; 'определение веса, взвешивание'; 'пошлина, сбор с веса товара'; 'система мер тяжести'; 'весы'; 'гиря' [СлРЯ XI-XVII вв. 2: 110-111] и многочисленные производные завъсъ,

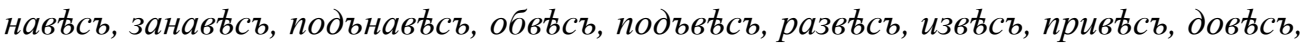

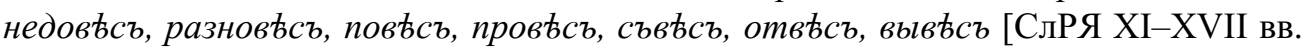
Справ. Вып.]; влр. вес, весить дополняется блр. навісу 'на весу' и млр. ві́сити, 
висіти. Констатируем корневой «ять». Выводится из праслав. сущ. *vе̌sъ, будто бы отвлеченного от глаг. *věsiti, соотносительного (с перегласовкой корня) с глаг. *visěti. Считается изолированным на и.-е. фоне [Etym. sl. stslav. 18: 1064]. Причины сохранения -s- в данной позиции также не выяснены, ср. сущ. веха. Между тем, сама собой напрашивается этимология раннепраслав. *visç-: *vīsç-: *v'aisç-: *vaisç'вихлять, вихрь, веха и т. д.)' < и.-е. глаг. с презент. суф. -sk- *ui-sk-: *uei-sk-: *uoisk-. См. вихлять, вихрь.

Санскр. viça 'a kind of weight $=20$ palas $=1 / 5$ tula' может оказаться внешним соответствием русск. висеть и вес, но явно иначе оформлено < и.-е. *ui-k-: *uei-k-: *иоi-k-. См. висеть, вихлять, вихрь.

Русск. въъшать (ся) (праслав. *věšati (sę)) др.-инд. veçáyati

В русск. словесности XI-XVII вв. изв. въщати 'вешать', 'взвешивать', 'подвергать смертной казни через повешение' [СлРЯ XI-XVII вв. 2: 133], а также производные навъшати, перевъшати, развъшати, извъшати, привъшати, повъшати, провъшати, вывъшати, вътатисл и повъшатисл [СлРЯ XI-XVII вв. Справ. Вып.]; влр. вешать, вешаться дополняется блр. ве́шаџь галаву́, ве́шащиа на шьі́ю и млр. вішати(ся), вішати; висіти. Констатируем корневой «ять». Из праслав. *věšati (se), итеративного глаг. на -(j)ati к *věsiti [Etym. sl. stslav. 18: 1064]. См. веc, весить, висеть.

Санскр. кауз. veçáyati, veçayate 'to enter' к глаг. viçáti, veçyate позволяет разрешить проблему фонологическую, но оставляет нерешенной проблему развития семантики. См. вес, висеть.

Русско-цслав. вътьъ (праслав. *větъ) санскр. veth, vith

В русск. словесности XI-XVII вв. изв. цслав. сущ. вътъ 'совет, договор' [Срезневский I, 6, 498; III, 681], 'увещание', 'совет, совещание', 'запрет, запрещение' [СлРЯ XI-XVII вв. 2: 122], завъть 'предание, завещание, закон', 'договор, соглашение', 'срок, предел', навъть, перевътъ, развътъ, извътьь, привътъ, повътъ, совътъ, съвъть, отъвъть, вывыть, глаг. вътовати 'возвещать, проповедовать, говорить' (Мин. ноябрь, 457. 1097 г.), извътити, отвътити, прилаг. завътьныи. Влр. привет, приветить, ответ, ответить, завет, завещать возможно дополняются блр. прывітаць, вітанне, прывітанне 'приветствовать; приветствие' и млр. вітати, вітання 'приветствовать, поздравлять, угощать; приветствие' (если это не гетерогенный омофон). Констатируем корневой «ять». Выводится из праслав. сущ. *větъ, соотносительного с глаг. *větiti (cp. ответ, привет, совет), которое некоторые возводили к и.-е. *uektos 'сказанный, изреченный, оговоренный' (?) [Etym. sl. stslav. 17: 1057-1058]. Однако, ни балтийские, ни индоиранские формы не дают поддержки данной реконструкции: др.-прусск. waitiāmai, waitiāt 'мы говорим, говорить', лит. vaitenù ‘сужу, обсуждаю, полагаю'; авест. vae $\theta a$ 'судебное заключение', vaet- 'установить судебным следствием’. Единственно возможная реконструкция праслав. основы *vět-<* vait- 'особый вид говорения, судебная речь(?)' с неясным и.-е. архетипом *weit(ว)-, *woito- 'to speak, adjudge' [Watkins IER 97; Etym. sl. Stslav. 17: 1058]. 
Вокализм и дентальный расширитель основы санскр. veth-, vethate или vith-, vithate 'to ask, beg' позволяют усомниться в верности общепринятой праслав. реконструкции и этимологии. Следует, однако, учитывать слабую аттестацию этого глагола, упоминаемого лишь в словнике Dhātupātha. Там же присутствует и форма с церебральным $t$ : vit-, vețati (также bet- betati) 'to swear, shout, address harshly; to speak', но она является вторичной от veth-, vith-, поэтому к значениям 'бранить, (грубо) кричать' нужно подходить осторожно. В любом случае, несомненно, что veth-, vith- относятся к речи и говорению. См. вече.

Русск. въче (праслав. *větje) санскр. veța, viț, vaița

В русск. словесности XI-XVII вв. изв. въче 'народное собрание'; 'тайное сборище, заговор против кого-л.', 'речь, увещевание, предречение' [СлРЯ XI-XVII вв. 2: 128-129] наряду с цслав. и ст.-болг. въште; ист. выче, диал. вече, вечье, вечье, веча (пск., новг., волог., арханг.) [Даль I, 189; СРНГ 4: 210]. Эта основа широко представлена в русско-цслав. словотворчестве: вещуать; завет, завещать; обет, обещуать; ответ, ответить, отвечать; привет, приветить, привечать; совет, совещаться; навет и т. п.; дополняется блр. ист. ве́че и млр. віче тж. Констатируем корневой «ять». Из праслав. *větje < раннепраслав. *vaitian, производного от сущ. *větz [Etym. sl. stslav. 17: 1057-1058]. См. вет, вещзать.

Санскр. veța, viț, vaita считают производными от глаг. vețati 'to sound' [Dhātup. ix, 29] и его варианта bețati 'to swear, shout, address harshly' [Dhātup. IX, 30]. Это этимологическое толкование не противоречит семантике др.-прусск. waitiaat 'говорить', wayte, woytis 'произношение' (при caryawoytis, karigewayte 'смотр войска', букв. 'военный совет'). См. вет.

Русск. въщщать (праслав. *větjati) санскр. vetati или veth, vith

В русск. словесности XI-XVII вв. изв. глаг. въщчати разговаривать, беседовать, предвещать, предрекать, предсказывать, наговаривать, ложно обвинять [СлРЯ XI-XVII вв. 2: 134-135], и приставочные производные завъщзати, навъщиати, обвъщати, предвъщати, извътити, отвътити и др. [Срезневский III, 684; СлРЯ XI-XVII вв. Справ. Вып.], а также др.-русск. вътовати 'говорить'. Влр. вещуать дополняется блр. вящчаць. Заимств. из цслав. (ст.-болг. извода), в конечном счёте восходит к праслав. *větjati, соотносительному с *větiti [Etym. sl. stslav. 17: 10571058]. См. вет, вече.

Какой санскр. глаг., vet, vetati 'to sound' или veth, vith 'to ask, beg' следует привлекать для сопоставления с праслав. *větjati, *větiti, остаётся неясным. Санскр. veta, vit, vaita считают производными от глаг. vetati 'to sound' [Dhātup. ix, 29] и его варианта betati 'to swear, shout, address harshly' [Dhātup. ix, 30]. Cм. вет, вече.

Русск. вина (праслав. *vina) вед. vená

В русск. словесности XI-XVII вв. изв. сущ. вина 'причина, основание; вина, провинность, проступок, грех; обвинение; осуждение, наказание, возмездие; то, что взимается в качестве возмещения ущерба; пошлина, повинность, обязательство' [СлРЯ 
XI-XVII вв. 2: 178-180]; влр. вина́ дополняется блр. віна́ и млр. вина́ тж. Восходит к праслав. сущ. *vina < *v'ainā 'проступок, ошибка, провинность' (закономерно ожидалось бы *věna, cp. *cěna), возникшему под влиянием глагольных образований на -vineti и возводимого обычно к и.-е. глаг. корню *uei-: *ūi- 'гнать, преследовать, вызывать страх; vice, fault, guilt' [Pokorny 1123-1124, 1175; Watkins IER 96; Etym. sl. stslav. 18: 1062-1063]. Выдвигалось предположение о заимствовании слав. слова из иранского [Lewy 1931: 114] в весьма короткой (один абзац) заметке и без сколько-нибудь развёрнутой аргументации, что послужило поводом для саркастического комментария со стороны Гуйера [Hujer 1933: 473] назвавшего её «небольшой, но, мягко говоря, бездоказательный вклад (nevelký, a nehrubě průkazný př́spěvek)» [Борисов 2015]. Гипотетически такое заимствование из ср.-перс. wināh- [wn's] 'грех' [MacKenzie 1986: 91] возможно, но очевидным фонологическим препятствием является вокализация корня и в слав., и в балтийских языках: лит. (диал.) vaі̃na 'ошибка, вина' [Palionis 1990: 356], vainóti ‘поносить, бранить, ругать, хулить', лтш. vaina 'вина', vainot 'винить, обвинять, пенять'; возможно еще др.-греч. aivó ‘ 'ужасный, смертельный’ и лат. vindex 'мститель' (букв. *vin-dek- 'назначающий пеню’).

Вед. сущ. vená-, venáh 'стремление, желание, забота' производно с причастным суф. -na- от вед. глаг. vī-, véti 'идти, стремиться, нападать, атаковать, наказывать, мстить', соотносительного с вед. глаг. inv-, ínvati 'наступать, нападать, теснить; применять силу', также возводимым к и.-е. глаг. корню *uei-: *uñ- 'гнать, преследовать, вызывать страх' [Pokorny 1123-1124, 1175]. Др.-инд. глаг. формы: vī, veti; 2. sg. véși also as impv. (RV); 3. pl. vyánti (RV, AV, Br.); Subj. 2. 3. sg. ves (RV); impv. vìtāt (ib.); 3. pl. viyantu (TS); p. A1. vyāná (RV); pf. vivāya, vivye (ib.); aor. avaișìt (Gr.); 3. pl. aveșan; Subj. veșat (RV); fut. vetā, veșyati; inf. vetum (Gr.) 'to go, approach' (either as a friend i. e. 'seek or take eagerly, grasp, seize, accept, enjoy', or as an enemy i. e. 'fall upon, attack, assail, visit, punish, avenge') (RV) [Monier-Williams]. Дополняется ср.перс. wināh- [wn's] 'грех' [MacKenzie 1986: 91].

Русск. висеть (праслав. *visěti) др.-инд. viçáti, veçyate

В русск. словесности XI-XVII вв. изв. висъти во многих знач. [СлРЯ ХІXVII вв. 2: 189]; влр. висеть дополняется блр. вісе́u̧ь и млр. висі́ти тж. Выводится из праслав. *visěti, производного глаг. на -е̌ti от основы *vis- и соотносительного c *věsiti, *věsz. Первоисточник, якобы, расширенная и.-е. основа *uei-s-: *uoi-s-: *ūi-s- 'раскачиваться из стороны в сторону, вертеться, поворачиваться', представленная также в праслав. *věxa, *vixrb. Остаются неясными причины сохранения и.-е. $-s-$ в данной позиции (рефлекс и.-е. палатального $-k$ - или итеративного суф. $-s c ̧-<$ и.-е. -sk-?) [Etym. sl. stslav. 18: 1064]. Отдаленные соответствия усматривали в др.-инд. viștara 'пучок тростника или травы для сидения', перс. $\bar{a} v \bar{e} z-, \bar{a} v \bar{e} x t-$ 'висеть, вешать', осет. awynzyn, awinzun 'вешать'; норв. veis 'сочный стебель'. Эти сопоставления вызывают больше вопросов, чем дают ответов. Все они не подсказывают решения проблемы праслав. нерегулярности.

Мы бы обратили внимание на санскр. глаг. viçáti, veçáyati, veçayate, veçyate 'to enter' [Monier-Williams], который, позволяет удовлетворительно разрешить 
проблему фонологическую (и.-е. *ui-k-: *uei-k-: *uoi-k-), но оставляет нерешенной проблему развития семантики. См. вес, весить, вешать, веха, вихрь.

Русск. витать (праслав. *vitati) санскр. vī, ve

В русск. словесности XI-XVII вв. изв. витати, обитати, наобитати, возобиmaти в знач. 'обитать, постоянно жить, поселяться где-л.' (ХІІ в.); 'жить, останавливаться где-л. временно, гостить' (XI-XII вв.), 'заезжать к кому-л., навестить кого-л.' (XVI в.), 'быть, находиться, пребывать' (XII-XIII вв.) [СлРЯ XI-XVII вв. 2: 192]. Влр. витать 'обитать, обретаться в каком-то месте' дополняется блр. вітаць

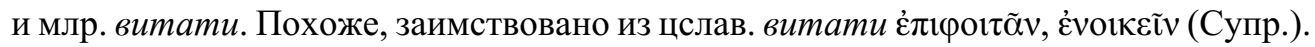
Считается, что первично значение 'быть, обитать', из которого развилось 'парить, носиться в воздухе’. Из праслав. *vitati, *obvitati, и.-е. архетип которого, вероятно *(a)ui- с дентальным расширителем основы (эпентетика?) [Pokorny 1123-1124; Etym. sl. stslav. 18: 1065-1066]. Сюда относили ещё лтш. разг. pavietāt 'квартировать' (?) и лтш. vieta, лит. vietà 'место, местожительства'; алб. vis 'место' (?); ил-

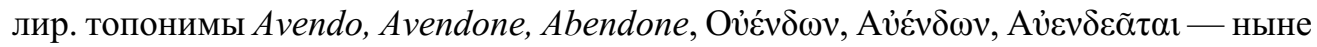
крепость Brlog, Kompolje, Lika, ЛИ Avendius Rufinus [Mayer I, 71], киммер. *auend'обитаемое жилье' в составе таврич. оронима Авинда [Шапошников // Этимология 2009-2011, 258].

Санскр. vi, ve также продолжает и.-е. архетип. *(a)ui-, который Ю. Покорный сводил к и.-е. корню *uei-3, *ueiz-: *ūi- [Pokorny 1123-1124]. Др.-инд. глаг. vī, veti; 2. sg. véși also as impv. (RV); 3. pl. vyánti (RV, AV, Br.); Subj. 2. 3. sg. ves (RV); impv. vìtāt (ib.); 3. pl. viyantu (TS); p. A1. vyāná (RV); pf. vivāya, vivye (ib.); aor. avaișìt (Gr.); 3. pl. aveșan; Subj. veșat (RV); fut. vetā, veșyati; inf. vetum (Gr.) 'to go, approach' (either as a friend i. e. 'seek or take eagerly, grasp, seize, accept, enjoy', or as an enemy i. e. 'fall upon, attack, assail, visit, punish, avenge') (RV) [Dhatup. xxiv, 39; Monier-Williams]. Но, скорее всего, эти др.-инд. глаг. формы имеют отношение к след. русск. глаг.

Русск. витъти, витити (праслав. *vitěti, *vititi) др.-инд. veț или vī, veti

В др.-русск. словесности XI-XIII вв. эта глагольная основа представлена в составе сложных антропонимов Витьбждъ, Витьбъ [Васильев 2012: 353, 353, 354, 616, 674], Витьньгъ [Васильев 2012: 100, 673, 730], Витимирь [Васильев 2012: 100, $160,161,676]$, а также в виде именной основы в составе Buтогость, Buтоньгъ, Buтонъ [Васильев 2012: 131, 675], Витославъ [Васильев 2012: 100, 209, 676], Гостивить, Гостовить, Гржзовить, Жидовить, Жьдовить, Лютовить, Нъговить и др. Обильная др.-русск. (новг.) ономастика позволяет реконструировать диал. глаг. *витьти, *витьғ;; *витити, *вичп, *витить и сущ. *витъ. В ст.-русск. языке известны глаг. витати 'приветствовать' (1605 г.) и витатися 'здороваться' (1582 г., 1694 г.) [СлРЯ XI-XVII вв. 2: 192]. Влр. диал. вита́mь, вита́ю ‘приветствовать’ дополняется блр віта́u̧ь и млр. вита́mu 'приглашать, приветствовать'. Скорее всего, из праслав. диал. *vititi, *vititb; *vitěti, *vitějetb < *v'ait- < *ueit-, см. веm.

В данном случае соблазнительно сопоставление с др.-инд. vet 'an exclamation used in sacrificial ceremonies' (VS). Ср. вет, вече, вещать. Но вполне допустимо 
и сопоставление с др.-инд. гл. vī, veti; 2. sg. véși also as impv. (RV); 3. pl. vyánti (RV, $\mathrm{AV}, \mathrm{Br}$.); Subj. 2. 3. sg. ves (RV); impv. vītāt (ib.); 3. pl. viyantu (TS); p. A1. vyāná (RV); pf. vivāya, vivye (ib.); aor. avaișit (Gr.); 3. pl. aveșan; Subj. veșat (RV); fut. vetā, veșyati; inf. vetum (Gr.) 'to go, approach' (either as a friend i. e. 'seek or take eagerly, grasp, seize, accept, enjoy', or as an enemy i. e. 'fall upon, attack, assail, visit, punish, avenge') (RV) [Dhatup. xxiv, 39; Monier-Williams].

\section{Русск. вихрь (праслав. *vix(ъ)rъ) санскр. vella}

В русск. словесности XI-XVII вв. изв. вихоръ, вихорь 'клок торчащих вверх волос, шерсти' (1626 г.), 'макушка' (1634 г.) и вихръ (вихоръ), вихрь (вихорь) 'вихрь' (XI-XII вв., 1677 г.), прилаг. вихрыи 'вихрастый’ (1582 г.) [СлРЯ XI-XVII вв. 2: 194]. Влр. вихор, вихр дополняется блр. віхор и млр. ви́хор тж. Следует отметить, что форма вихорь вместо вихръ появилась в результате смягчения конечного согласного в стечении - $x p b$, ср. параллельное вихорь 'вихрь' с вокализацией плавного. Восходит к праслав. *vixъrb, производному с суф. -ъrb от основы *vix-, соотносительной с *věxa, *vy-vix-noti. Или продолжает праслав. *vixrъ, производное с (адъективным?) суф. -r- от основы vix- 'раскачиваться из стороны в сторону, вихлять' (см. вихлять, др.-русск. вихляти), вероятно восходящей к и.-е. диал. расширенной основе *uᄉi-s-: *uei-s-: *uoi-s- 'вилять, виться, вихлять; вихрь' предположительно относящейся к и.-е. корню *ŭ̆- 'разделяться, раздваиваться' или же к экспрессивному корню *ŭ̆-, *uoi- с экспрессивным расширением - $x$ - <-sk- [Etym. sl. stslav. 18 : 1061-106]. Ср. вост.-лит. víesulas 'вихрь', лтш. viesulis тж.

Санскр. прилаг. vella- 'going, moving, shaking' производно от глаг. vel- (vell-), vellati 'трястись, дрожать, качаться, быть кинутым или быть возбуждённым; двигаться' [Monier-Williams], который имеет, согласно Dhātupātha, параллельную форму vehl-, vehlati, являет вместе с ней разные стадии ассимиляции стечения согласных $h l$. Корень vel- закономерно возводится к *ui-l-: *uei-l-: *uoi-l-, а его вариант vehl- к расширенной основе *uei-g $\hat{g}^{h} l$-, в котором и.-е. диал. расширение основы $-z h l-<-\hat{g}^{h} l-$, вероятно, также выполняло экспрессивную функцию. Несмотря на то, что прилаг. *vehla- не засвидетельствовано в др.-инд. лексикографии, оно гипотетически возможно. Следует отметить, что vella- *vehla- больше соответствует *vixrb, нежели форме *vixъrъ. При этом нужно иметь в виду, что при кажущемся сходстве, звук $h$ в санскр. vehl- и $x$ в праслав. *vixrb, *vixl'ati разного происхождения (- $\hat{g}^{h} l-$ и $-s-/-s k$ - соответственно), но их объединяет экспрессивная функция. См. вихлять.

Русск. вихлять (праслав. *vixl'ati) санскр. vehlayati

В ст.-русск. книжности XVII в. изв. вихляти, хрептомъ вихлаєтъ, вихляниє, вихлятыл [СлРЯ XI-XVII вв. 2: 194]; влр. диал. вихлять, вывихнуть дополняется блр. віхляц̧ь, віхляц̧иза 'вихлять, махать, вихляться', диал. віхліu̧ь 'вилять хвостом, хитрить' и млр. вихати, вихляти, вихлювати 'махать; колебать, покачивать' . Невзирая на позднюю письменную фиксацию, весьма древняя группа глаголов. Экспрессивное нагнетание суффиксов имеет ещё праслав. происхождение: 
*vixati, *vixneti, *vixl'ati < *v'ais-, *v'aisk- (?), при этом только *vîxl'ati < *v'aisklили *vîxъl'ati < *v'aisul- имеют все регулярные фонологические мены. Первоисточник - и.-е. глаг. *uеi-: *uoi-: *ūi- 'вертеться, поворачиваться' [Pokorny 1120] с расширением основы $-s$ - или $-s k$ - (?). Ближайшую родственную форму усматривали в лит. viesulas 'вихрь'. Но не следует оставлять без внимания и проницательное сопоставление К. Буги [Буга // РФВ 75: 153] с лит. глаг. viskéti, viskù 'колебаться, находиться в движении'. См. веха, вихрь.

Санскр. vehlayati явл. кауз. формой глаг. vehlati 'to cause to shake', 'to shake about, tremble, sway', 'be tossed or agitated' [Monier-Williams], который допускает индоиранскую реконструкцию *vaizhlayati; *vaizhlati < *ueighl-, в котором и.-е. диал. расширение основы -zhl- $<-\hat{g}^{h} l$ - вероятно также выполняло экспрессивную функцию, как и праслав. -xl- < -skl-, ср. санскр. алломорф vellayati; véllati. Несмотря на очевидное различие расширителей основы, этимологическое родство русск. и санскр. глаголов весьма вероятно. Ср. этимологию русск. веха, вилять, виляет.

Русск. ворон, ворона (праслав. *vornъ, *vorna) вед. várna-

В русск. словесности XI-XVII вв. изв. воронъ (1074 г.), ворона (1483, 1673 гг.), русско-цслав. врана, вранъ [СлРЯ ХІ-XVII вв. 3: 33] и ст.-русск. Жаворонъ (прозвище ок. 1600 г.) [СлРЯ XI-XVII вв. 5: 68]; влр. во́рон, воро́на дополняется новороссийским словосложением гайворон, грайворон, ст.-блр. воронъ, блр. топонимом Воранава и млр. диал. ворон, ворін, орон, воро́на. Из праслав. *vornъ, *vorna < *vârnas, *värnā по этимологии которого не достигнуто консенсуса [Etym. sl. stslav. 18: 1081]. Согласно распространённому мнению, это - производное с суф. - $n$ - от и.-е. глаг. *uer- 'гореть, обгорать, делаться чёрным' [Pokorny 1166], но возможны и иные объяснения, например, через звукоизобразительные основы типа *uer(ə)- 'to speak' [Pokorny 1162] и др. Родственные слова, обычно привлекаемые в сопоставительные ряды с русск. воронъ, ворона: др.-прус. warnis, warne, лит. var̃nas, várna, лтш. vārna $<$ *ū̄rnā- 'Corvus cornix, corone', тохар. В wrauña 'ворон, ворона'.

Вед. várṇa-, várnah 'внешний вид, форма, фигура; цвет, краска, пигмент’ дополняется авест. varznah 'цвет' [Bartholomae 1372] и может быть убедительно истолковано как производное с суф. -na- от вед. глаг. vr-, vrnóti, -te, vrnuté (также отмечены и формы с полным вокализмом корня várati, -te) 'покрывать, занавешивать, скрывать, окружать', очевидно, не имеющего ничего общего со значением 'гореть, чёрный' и поэтому не связываемому в словаре Ю. Покорного [Pokorny 1166] с и.-е. *uеr- 'гореть, обгорать, делаться чёрным', а возможно, относящемуся к и.-е. *uer- 'вращать, поворачивать, крутить' [Рokorny 1160] с семантическим развитием: 'скрыть из виду путём заворачивания'. При явном расхождении значений и сходстве фонетического облика предполагаемых и.-е. прототипов *uer- для праслав. *vornъ и вед. várṇa- сопоставление этих слов кажется оправданным, если принять за основное значение не 'чёрный < обгорелый', а 'окрашенный (в чёрный цвет), имеющий цвет’, что может быть мотивированно распространённым во многих культурах мира мифологическим мотивом о том, что ворона была изначально белой, но была окрашена, приобрела свой цвет в наказание, см. подробно в публ. 
А. Коротаева [Korotayev 2006: 472-520]. Примечательно также и широкое распространение этого слова в уральских языках: фин. vares, varis, ненец. warya, warye 'ворона' и др., что может оказаться древним заимствованием из и.-е. языков. Предположение о заимствовании из уральских языков в и.-е. весьма сомнительно. Невысокий рейтинг сопоставления отражает противоречивость современного состояния этимологии этих слов.

Русск. вороп (праслав. *vогръ) санскр. varph

Др.-русск. сущ. воропъ, наворопъ 'налет, нападение, ограбление' (ПВЛ Лавр., Ипат. Лет.), пустити на воропь 'начать стремительное наступление' (1157 г.) [СлРЯ XI-XVII вв. 3: 34], глаг. вьрn8, вьрпсти 'рвать, грабить', вероятно, не избежали воздействия цслав. наврапъ 'грабеж, добыча'. Влр. диал. обычное определение жениха и каравая воропа́ŭ, фамильное имя Воропа́ев сохраняют пережитки этого слова. Реконструируется праслав. сущ. *vorpъ, регулярного вида производное от глаг. *vbrpsti, *vbrpe из и.-е. *uerp-, *urep- 'to turn, wind' [Watkins IER 99], этимология которого может быть связана с лит. лексическим гнездом virpčioti 'подрагивать, вздрагивать', virpéjimas 'колебание, трепет, дрожь', virpéti 'колебаться, дрожать, трепетать; вибрировать', virpinti 'заставлять вибрировать, колебаться', virpintùvas 'вибратор', virpstas 'шест', virpteleti 'дрогнуть', vir̈ptis 'тычина, шест', virpulÿs 'трепет', virpiúoti 'дрожать, подрагивать', лтш. virpulis 'вихрь, круговорот, водоворот', virpuḷšana 'вихревое движение', virpuḷot 'кружиться, вихриться', virpuḷvētra, virpulviesulis 'смерч', прагерм. *wrap- 'to wrap, to turn, to wind' [Watkins IER 99].

Санскр. глаг. varph, varphati (гл. 1 класса) ‘to go’ или 'to kill’ (L.) считается очень тёмным и встречается только в словарях. Неясна его и.-е этимология: возможно, из того же и.-е. *uerp-, *urep- 'to turn, wind' [Watkins IER 99]? Вероятно и он сопоставим с др.-греч. $\dot{\rho} \varepsilon ́ \pi \omega$ (из *urepō) 'качаюсь, склоняюсь, перевешиваю',

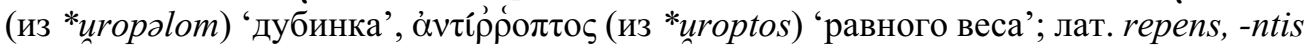
'внезапный, неожиданный'. Балто-славянский и индо-греческий лексический материал позволяет наметить контуры первичной семантики и вектор семантического развития слов этой группы. Кроме того, это сопоставление даёт отсвет типологической аналогии на русск. лекс. гнездо вес, веха, висеть, вихрь.

Русск. внук (праслав. *vъnukъ) санскр. ánuka

В русск. словесности XI-XVII вв. встречаются сущ. вън8къ, правн8къ, праправн8къ, а также вн8ка 'внучка' [СлРЯ XI-XVII вв. 2: 244, 246]; влр. диал. внук, уну́к (севск.) дополняется блр. уну́к и млр. ону́к. Из праслав. *vъnиkъ, производного с суф. -ukъ от корня *vъn- (начальный $v$ - протетического происхождения). Корень * $n$ - стало привычным возводить к редуцированной ступени огласовки и.-е. корня *an-: *n-, издревле обозначавшего различные термины родства 'дед или бабка; предок; приёмная мать свекровь', и, таким образом, относить к словам «детской речи» [Etym. sl. stslav. 18: 1102-1103]. Обычно привлекаемые внешние и.-е. соответствия: др.-прусск. ane 'бабушка', лит. anýta 'свекровь', др.-греч. óvvís 'бабушка', лат. anus 'старуха', апnа 'приемная мать', др.-в.-нем. апо 'предок', ana 'бабка' и др. только 
усугубляют трудности интерпретации семантического развития от 'предок, бабка, старуха, приёмная мать, свекровь' к 'потомок, внук'. Для объяснения причудливого семантического развития привлекалась типологическая «инверсия названия». См. различные точки зрения в публикациях прошлых лет [Трубачёв 1959: 71-76; Stankiewicz 1962; Friedrich 1966]. Заимствование слова из слав. яз. в лит. anūkas 'внук' случилось относительно поздно. Реконструкция раннепраславянского состояния *vъnukb $<$ *an(u)aukas выявляет суф. -ukъ $<*$-aukas и корень *anu-, *anv-, который и в формальном, и в семантическом плане ближе к санскр. ánuka, в чём следует согласиться с А. Вайаном [Vaillant // RÉS 11: 206] и усомниться в толкованиях Г.А. Ильинского, С. С. Младенова, О.Н. Трубачёва.

Санскр. прилаг. ánuka- 'подчинённый, зависимый' (буквально 'бывающий после') несомненно разделяется на вед. наречие ánu 'после, впоследствии, вслед, затем, дальше', закономерно возводимое к и.-е предлогу *aпu, *aп̄̄ 'вдоль, после и др.' [Pokorny 39-40], и продуктивный сравнительно-уменьшительный суф. -ka. Совпадая с раннепраслав. реконструкцией русск. внук в корневой части, др.-инд. форма отличается простотой первичной суффиксации (основа на $-u-+$ суф. $-k a-)$.

Русск. второй (праслав. *vъtorъ) др.-инд. itara либо vítara либо ántara

В русск. словесности XI-XVII вв. изв. числ. въторъ, въторъ, второи, въторыли [СлРЯ XI-XVII вв. 3: 165-166]; влр. второй дополняется блр. уторы и млр. вто́puй. Согласно одному мнению - праслав. числ. *vъtorъ тождественно лат. uter 'который из двух’ [Mikkola 1908: 16]. В таком случае следовало бы говорить о старом заимствовании и фонетической адаптации в средне-дунайском праславянском из колониального латинского Дакии. Согласно второму мнению - из праслав. *vbtorb(jb), восходящего к и.-е. *ui- 'врозь, далеко друг от друга' с суф. сравнит. степ. прилаг. -ter-: -tor- [Педерсен // KZ 38: 395; Младенов // KZ 44: 371]. Других примеров русск. рефлексов и.-е. *uі- привести не удаётся. Согласно третьему мнению - из праслав. *vъtorъ $(j b)$ в ступени редукции и.-е. *noteros 'внутренний, другой' [Meillet Études 407; Idem // IF 5: 329; Idem // MSL 8: 236; 10: 140; Idem // RS 3: 167; Idem BSL 29: 35; Falk, Torp 1910-1911: 27 и сл.; Mikkola // BВ 22, 253; Trautmann // AfslPh 38: 130; Idem BSW, 10 и сл.; Idem Apr. Sprachd. 301; Etym. sl. stslav. 18: 1109-1110]. Однако, рефлексов гипотетического и.-е. диал. *nteros

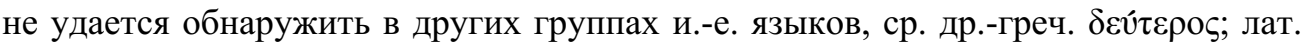
uter 'который из двух'.

В этой ситуации трудно остановить свой выбор на каком-то одном санскр. соответствии. Либо перед нами аналог 1) др.-инд. itara 'another, the other (of two)', либо 2) др.-инд. vitaras 'ведущий далее', vitarám 'дальше', авест. vitara- 'дальше' - сравн. степ. от др.-инд. vi 'врозь', либо 3) др.-инд. ántaras 'другой’, туранск. *antara- (осет. ændær) (?).

Русск. верх (праслав. *vbrxъ) вед. varșma или санскр. vrkșa?

Др.-русск. сущ. върхъ 'верх, вершина' известно с IX в., а также вьрхъ, вьрьхъ, верхъ, връхъ 'верхняя оконечность чего-л., вершина, верхушка; темя, макушка, 
голова; купол, глава церкви; потолок, кровля, крышка; царский дворец, внутренние царские комнаты; оболочка чего-л., наружная ткань одежды, головных уборов, имеющих подкладку' и перен. 'то, что завершает, увенчивает что-л., стоит во главе чего-л.; победа’ и т. д. [СлРЯ XI-XVII вв. 2: 100-102]; влр. верх дополняется млр. верх и блр. верх. Большинство славянских этимологов [Machek ESJČaS (1957); Фасмер I (1964) 301-302; БЕР I (1971) 190-191; 574; Skok III (1973) 624-625; Boryś SEJP 695; Rejzek ČEJ 789-790; Kralik SESS 670; Pokorny 1108, 1151-1152] возводит праслав. *vbrxъ, основу на -u: -ъv-, к расширенной основе *uer-s-, производной от и.-е. корня *uer- 'возвышенность, возвышенное место; high raised spot or other bodily infirmity' [Watkins IER 99] или к *urs- $u$ тж [Derksen 538]. Близкородственными словами считаются лит. viršùs, лтш. virsus 'верх', virsa, vilciņš; хетт. глаг. uaršs-tta(ri), uaršiiela-zi 'поднять(ся)' [Kloekhorst 2008; 969]; лат. verrūca 'возвышение, бородавка'; ирл. ferr 'лучше'; с большими сомнениями др.-греч. оúpăvó ` 'небеса, небесный свод’ (если из *uorsanos). Балтийский сопоставительный материал бросает тень на эту этимологию (лит. $\check{s}$ может быть рефлексом как и.-е. $k$, так иногда и $s$ после $r$ ), ассимилированные лат. и ирл. формы также её не подтверждают из-за неясности внутренней реконструкции (лат. сущ. verruca может оказаться однокоренным праслав. *verdъ, *verditi 'бередить рану’, хеттские формы могут являться порчей и упрощением иных прототипов). Предлагаем альтернативную этимологию: позднепраслав. *vbrxъ закономерно продолжает сред.-праслав. *virxu- из раннепраслав. *vrks- 'любое дерево, лес' (?), ср. синдо-меот. или скиф. топ. Врі $\xi \alpha \beta \alpha$ ‘видное дерево (на холме?)’ или 'покрытый деревьями; covered with trees'. Эта этимология позволяет предположить иное происхождение слова, иное словообразование. Перед нами отглагольное сущ. от не сохранившегося праслав. рефлекса и.-е. презентного глаг. *vrk-sk-ō. См. вершие, вериина.

Санскр. сущ. vrkșa м. p. (ж. p. $\bar{a}$ ) 'любое дерево, особенно несущее цветы и плоды', часто 'лес' инд. лексикологи считали производным от глаг. 2 класса $b r h$ 'pacти’ или от глаг. 1 класса $b r h$ 'to root up', что очень сомнительно. Не более вероятно образование этого сущ. от глаг. 6 класса vraśc- (cf. $\sqrt{ } v r k$ ) (Dhātup. XXVIII, 11), vrśscati, прич. прош. vrknnan (BhP.); сврш. vavraśca, -citha (Gr.); aop. avraścīt, avrākșīt (Ib.); vrksși (Br.); буд. vraścitā, vraștāa (Gr.); vraścișyati, vrakṣyati (Ib.); ind. p. vraścitvā (Ib.); vrșțā (AV); vrktvī (RV); -vraścam, -vrtcya (Br. \&c) 'to cut down or off or asunder, cleave, hew, fell (a tree)' (RV \&c \&c): страд. vrśsyate (в AV также vrśscate), 'to be cut down or off \&c': кауз. vraścayati (aop. avavraścat) (Gr.): пожелат. vivraścișati, vivrakṣati (Ib.): интенс. varīvrśscyate, varīvrtcīti (Ib.) [Monier-Williams]. Ни праслав., ни санскр. этимологию нельзя признать убедительной. Этимологические изыскания следует продолжать.

Русск. вершина (праслав. *vbršina) вед. varṣmán-, varșmá

В русск. словесности XI-XVII вв. изв. сущ. вершина [СлРЯ XI-XVII вв. 2: 108]; влр. вериина дополняется млр. вериúна и продолжает праслав. *vbršina, производное с суф. -іпа от *vbrxъ с регулярным перебоем - $x$ - в -̌́- перед -j-. См. верx. 
Вед. varșmán-, varṣmá (также и м. p. varșmán-, varșmā) 'height, top; высота, верх, поверхность, высшая часть; величие, протяжение; тело’ морфологически разделяется на корень varș-(vrș-) и суф. имени действия -man-, стоит в одном ряду c várșīyas- 'выше, длиннее, больше' и varșiștha- 'самый высокий, высший, длиннейший, величайший' и будто бы закономерно возводится к и.-е. корню *uer-: uer-s-. При этом обращает на себя внимание изолированность предполагаемого корня *varṣ-(vrṣ-) в др.-инд., не имеющего сколько-нибудь фонетически подходящего реального глагольного прототипа, кроме вед. глаг. vrș-, varșati 'лить, изливать, литься (гл. обр. о дожде)', явно не подходящего по значению. Также необычно и отсутствие сколько-нибудь надёжных параллелей в других и.-е. языках (даже в авест.), кроме балт. и слав. Древнеиндийские грамматики решали эту проблему по-разному, иногда утверждая, что санскр. varșman производно с суф. -man- от основы глаг. várdhate, vṛidh 'вырасти, стать высоким' и предполагая в várșīyas- и varșiștha- степени сравнения от vrddha- 'выросший, большой, огромный' [Рāṇini 6-4, 157], отвлеченного от глаг. vrdh-, várdhate 'увеличиваться, возрастать, расти, подниматься и др.'. Напомним, что Панини характеризует уникальное языковое чутьё. И он может оказаться более проницательным, чем современные европейские лингвисты. Такая этимология отрывает слова этой группы от и.-е. реконструкта *uer-, *uer-s(эта возможность даже не упоминается, напр. в словаре Майрхофера [Mayrhofer 3: 160-161]). Правда, известен аналогичный казус с основой *ard-: *arz- (др.-инд. ardh-: rș- ‘течь') в палеобалканской гидронимии. Примечательно, что все три вед. производных от *varș-(vrș-) сочетают в себе значения 'высокий’, ‘длинный, протяжённый' и 'большой, великий'. Словообразовательные суффиксы и ступени корневого вокализма разные в сопоставляемых языках. См. вершие, верх.

Ст.-русск. вьршиє, верииє (праслав. *vbř̌sje) вед. várșīyas

В русск. словесности XI-XVII вв. изв. сущ. вьршиє, верииє ср. р. 'верхние части ветвей', 'плоды дикорастущих деревьев', прилаг. вершии 'верхний' [СлРЯ ХІXVII вв. 2: 107-108]; влр. навершие не имеет блр. и млр. дополнений. Восходит к праслав. *vbršbje, производному с суф. -ьje от *vbrxъ. Обратим внимание читателей на удивительную семантическую близость др.-русск. слова и др.-инд. vrkșa. См. верx.

Вед. прилаг. várșìyas (várșìyah) 'выше, длиннее, больше чем; очень большой, значительный, важный' возводился европейскими лингвистами к и.-е. корню *uer-: *uer-s- 'возвышенность, возвышенное место' [Pokorny 1151-1152], но может оказаться результатом упрощения формы *varkșiya-. См. подробно коммент. к верx. Древнеиндийские грамматики решали эту проблему, предполагая в várșìyaи varșiștha- степени сравнения от vrddha- 'выросший, большой, огромный' [Рāṇini 6-4, 157], что отрывает их от сущ. varșmán- < и.-е. *uer-: *uer-s- (такая возможность даже не упоминается, напр. в словаре [Mayrhofer 3: 160-161]).

Русск. весь, вся, всё (праслав. *vbsb, *vbs'a, *vbs'e) др.-инд. viṣu или вед. víśva

В русск. словесности XI-XVII вв. изв. мест. вьсь, весь, вься, вьсе [СлРЯ ХІXVII вв. 2: 121-122]; влр. весь, вся, всё, все дополняются блр. уве́сь и млр. уве́сь, 
$y c e ́, y c я ́$. Восходит к праслав. *vbsb, *vbs'a, *vbs'e, относительно и.-е. этимона которого нет единого мнения [Etym. sl. stslav. 18: 1116-1117]. Согласно распространённой трактовке, слово образовано от рефлекса и.-е. *ǖ- 'врозь, надвое, два' с расширением -s- [Pokorny 1176], но в таком случае ожидались бы закономерные формы *vbx-> *vbšb (!?). Ср. др.-прусск. wissa 'весь', лит. visas и лтш. viss 'весь, целый'; возможно, иллир. (агафирс.) *ves- в составе антропонима Vesclevesis (архетип слав. Вьсеславъ?). В случае выведения праслав. *vbsb из и.-е. *uй-s- оно оказывается родственным др.-инд. нескл. нареч. vișu 'с обеих сторон, с разных сторон, равно, одинаково' (в вед. отмечена также форма вин. п. ср. р. ед. ч. vișvam (< vișuvam) 'на обеих сторонах, в обоих направлениях'). Все эти этимологии неудовлетворительны в фонологическом отношении. Слово может быть закономерно возведено и к и.-е. *uйk $\hat{k}$-, аналогично устар. весь 'поселение, деревня'. Если допустить для праслав. *vbsb исходный и.-е. архетип *uূ̆- $\hat{k}$-, то прямое родство с др.-инд. víśva- становится более чем вероятно.

Вед. прилаг. viśva- 'весь, всякий; каждый; цельный, полный, универсальный' и соотносительное сущ. ср. p. víśva-, víśvam 'целый мир, вселенная' [MonierWilliams] дополняются др.-перс. vīspa- 'весь' и толкуются как образования с абстрактным, обобщающим суф. -va- от вед. глаг. viś-, viśáti, -te 'входить, проходить внутрь или располагаться на'; все они формально возводятся к и.-е. корню *uйс расширителем $\hat{k}$-. С другой стороны, смешение похожих по звучанию свистящих ś и $s$ иногда встречается в др.-инд. В последнем случае сведение балто-славянских и индоиранских однокоренных слов к единому и.-е. архетипу *u厶 на непреодолимые фонологические трудности, особенно в отношении праслав. реконструкта. Невысокий рейтинг сопоставления отражает различную суффиксацию и противоречивость и.-е. этимологии.

\section{Русск. заяи (праслав. *zajęcь) санскр. häya}

В русск. словесности XI-XVII вв. иЗв. Зағац̧ь, ЗағАц̧а, заАц̧ь, Заяц̧ь, род. П. Заяцุа, прилаг. заячиии, заєчии [Срезневский I, 2: 961]; влр. заяц дополняется блр. заяц и млр. заяџь, зайча, зайченя, зайчик, зайчиха, зайчичя, заячий. Большинство этимологов выводит слово из праслав. *zajęcb, производного с суф. -есь (ср. меcяu) от основы *zaj-, соотносительной с глаг. *zijati, *zinqti, *zěvati и восходящей в конечном счете к и.-е. *ghau-, ghēu-, $g h \bar{e} u$-, ghāi-, $g h \bar{e}$ - 'to yawn, gape' [Pokorny $419,449]$. Мотивация наименования зверька — якобы его «заячья» губа. Соответ-

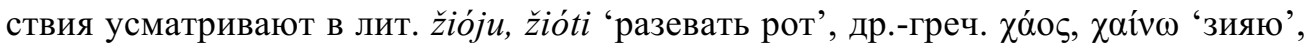
$\chi \alpha ́ \sigma \mu \alpha$ 'yawning gulf', лат. hiare 'зиять', hiatus 'зияние', прагерм. *ginōn 'to yawn'. Но не менее убедительна альтернативная этимология из праслав. *zajęc, произ-

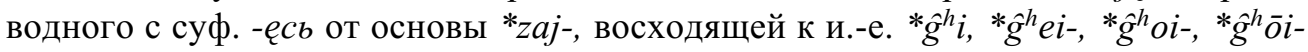
'to propel, prick; прыгать, скакать; проворный' (бытовала и расширенная основа * $\hat{g}^{h}$ oi-dh-) [Pokorny 424]. Ср. лит. žáidžiu, žáisti 'прыгать'; арм. jii 'конь'; лат. haedus 'козёл'; гот. gaits 'коза' и прагерм. *gaidō 'goad, spear'. К сожалению, такой производящий глаг. в праслав. не представлен [Etym. sl. stslav. 18: 1120$1121]$. 
Санскр. háya, hắya, hāyas, hi < *3haias, *3hāias, *3hāiasa, *3hi 'a horse; конь (скакун)' и производные от него sarváhāyas, vihāyas, с одной стороны подтверждают этимологию арм. $\hat{j} i$ 'конь', а с другой — праслав. *zaj- < *zāi $\bar{i}$. Архетип: и.-е. глаг. $* g^{h} i$, * $\hat{g}^{h} e i-$, $* g^{h} o i-,{ }^{*}{ }^{h} \bar{o} i$ - 'прыгать, скакать', к которому возводят и санскр. глаг. himsati 'he injures' < * ghi-n-s- [Pokorny 424; Watkins IER 28]. В данном случае, первичное значение было 'прыткий, проворный, скакун, прыгун'.

Русск. звено (праслав. *z(ъ)veno) санскр. ghuп̣a

В ст.-русск. языке XVI-XVII вв. изв. звено 'отрезок большой рыбы от позвонка до позвонка' (1547 г.), чепь серебряна... у неи 11 звенъ литые на проюмъ 'одно из колец, составляющих цепь, кольцо в цепи’ (1589 г.) [Срезневский I, 2: 963]; влр. сущ. звено дополняется блр. звяно тж. Возводят к праслав. *z(b)veno, будто бы соотносительному с вост.-слав. *po-z(ъ)von-ъkъ (перегласовка *po-z(ъ)ven-ъkъ?), формально приставочным производным с суф. -ъkb от корня $*_{z}(b) v o n-$ Большинство этимологов возводит эти слова к глаг. звенеть, звонить по внешнему созвучию. Некоторые предполагали раннюю перестановку согласных *zeno из *zenvo, якобы

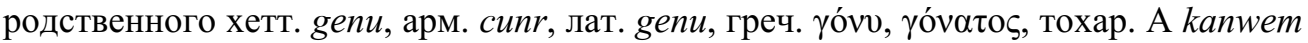
'колено'. Не более вероятно толкование из гипотетического праслав. **zъvb 'рыба'

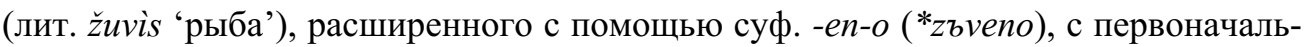
ным знач. 'часть рыбы от позвонка до позвонка'. В свете др.-инд. данных этимология этого слова видится иначе.

Санскр. ghuna 'вид древесного насекомого, «обходящий вокруг»' является производным от глаг. ghónate, ghunáti, ghun 'to go or move about; обходить, двигаться вокруг', именно знач. кругового движения представляется первичным и для русск. звено. Из-за неуверенности в этимологической части рейтинг сопоставления невысок.

Русск. звон (праслав. *zvonъ) санскр. svāna

В русск. языке XI-XVII вв. изв. звонъ 'звон колокола, колокольный звон' и 'кимвал' [Срезневский I, 2: 964]; влр. звон 'действие звонящего', 'сам звук, гул (колокола)' дополняется блр. звон, род. П. звана́, звону 'колокол; звук, трезвон; сплетни, толки' и млр. диал. звін, дзвін, род. п. дзво́на 'колокол; звон, трезвон'. Из праслав. *zvonz, производного с перегласовкой корня (*zvbn-: *zvon-) и темой -ъ от глаг. *zvbněti, предполагаемый первоисточник которого и.-е. корень * $\hat{g}^{h} u e n-:$ * $g^{h}$ uon-, cp. алб.-тоск. zёh 'голос', гег. zah из и.-е. * $g^{h}$ uоonos; арм. jain. Согласно другому толкованию это слово целиком продолжает и.-е. сущ. *suonos (лат. sonus), производное от глаг. *suеnә- 'звучать' [Pokorny 1046] с преобразованием анлаута под влиянием слов званый, зову, звать. Ср. звонить, звенеть; званый, звать, зовёт.

Санскр. svāna образовано от глаг. svan 'to sound, make any noise, roar, yell, hum, sing' и восходит к и.-е. *suonos, ср. лат. sono, sonavi, sonatum, sonare 'звучать', др.в.-нем. swan 'swan (the sounding bird)' [Watkins IER 88]. Эта этимология может служить вероятностным обоснованием второй этимологии русск. слова звон. 
Русск. здание (праслав. *zidb, *zizbdb) др.-инд. dehī, degdhi

В русск. языке XI-XVII вв. изв. цслав. (ст.-болг.) зидъ 'стена, постройка' и русско-цслав. зиданиє, зьданић, зеданиє, зданић 'строительство', ‘то, что создано кем-то', 'назидание', имена деятеля зидарь, зьдарь, здарь, зидатель, зьдатель, зидецъ, зодецъ, ждетель, зиждитель, зижитель 'строитель, создатель', глаг. зидати, зьдати, здати, зиждж, зижћ и зидаћ, зидањщии, зижджщии, зижжиии, зидатисл, здатисл 'созидать, сотворить', 'воздвигать, строить', сущ. зиздъ, зиздь 'крепостное сооружение, заграждение, стена, вал' (XII-XIV вв.) и однокоренные ему зизданиє, зиздатель, зиздати [СлРЯ XI-XVII вв. Справ. Вып.]. Русскоцслав. зиздь вышло из употребления. Остатки этой лексико-семантической группы: здание, назидание, созидание, создание, создатель, созидать, создать и т. п. Из праслав. *zidb < *z'aidas < раннепраслав. *d'aizas и удвоенной основы $*_{z i z b d b}$ $*_{z i z b d b}<*^{\prime}$ 'aizdi-, *dizd'ai- (если перед нами не вост.-слав. передача болг.-макед. рефлекса зиждь праслав. *zidjb?!), производных от глаг. *zidati, *zidajo < *zaid$<*^{\prime}$ 'aiz- и $*_{z b d a t i, ~ * z i d j o}<*_{z i d-,} *_{z}$ 'aid- < *diz-, *d'aiz-, ср. созидать, зиждитьcя. Метатеза (перестановка согласных) произошла в позднепраславянском языковом состоянии, так как палеобалканский ареал знал только исправные формы diza, dizas, deizas 'стена, крепость'. И.-е. архетип (2 алломорфа) *dhigh- *digh-: *dheigh- * *igh-: dhoigh- * *doigh- также дал рефлексы в виде финейск. $\delta i \zeta \alpha$,

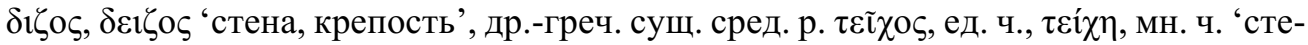
на, стены' [Pokorny 244].

Санскр. dehī дополняется авест. daeza 'a wall made of clay or mud bricks' восходит к и.-е. алломорфу (варианту) $* d o i \hat{g}^{h}$-, с отличной от праслав. ступенью корневого вокализма. При формальной близости цслав. зидъ семантика санскр. отглаг. сущ. dehī 'mound, bank, rampart, surrounding wall; to anoint, smear, plaster' ближе вост.слав. основе с удвоением *zizbdb, ныне вышедшей из употребления, ср. санскр. удвоенные глаг. основы degdhi, digdhe.

Др.-русск. жер (е)ти (праслав. *žerti, *žbrti) вед. jẹ-, járate

В русск. языке XI-XVII вв. изв. др.-русск. глаг. жерети, жьроу, жьреть 'приносить в жертву', жрети, пожьрети, жряху, жьрти, жьроу, жьреть [СДРЯ III, $250,275]$ и цслав. ж(b)pъти, жьрд, пожрьти 'совершать жертвоприношение, священнодействовать', 'служить, поклоняться кому-л. (божествам, идолам)', 'исповедовать какую-л. веру', жрғтися 'приноситься в жертву' [СлРЯ XI-XVI вв. 5: 123; Срезневский II, 1084], а также однокоренная глаг. основа в именах композитах старшей серии: Жьръбвдъ, Жеребуд [Васильев 2012: 98, 252, 320] 'жреть будущее’; Жьрым(ир)ъ, гипокористика Жерем [Васильев 2012: 400, 401, 402] 'жреть судьбу'; Жьрьмысль [Васильев 2012: 253] 'жреть промысел'; Жьрыславъ, Жераслав, Жереслов, гипокористика Жьрыта, Жерета [Васильев 2012: 84, 85, 252, 311, 324, 325, 670, 730] 'жреть славу'. Восходит к праслав. глаг. *žerti, *žbrti 'совершать жертвоприношение', возводимому к и.-е. $g^{w} e r(\partial) 4-$ 'поднимать голос, славить' [Pokorny 478], при этом нет фонологических препятствий возвести его и к и.-е. экспрессивному глаг. *gerz2- ‘пронзительно кричать' [Pokorny 383]. Ср. др.-прусск. girtwei 
'хвалить', лит. giriù, gýriau, gìrti ‘хвалить, прославлять', лтш. dzir̃t 'славить', dziřrtiēs 'хвалиться, напоминать о себе'.

Вед. $j \bar{r}-$-, járate не имеет однозначной этимологии [Mayrhofer 1: 421], но не без оснований считается некоторыми [Whitney 1885: 55; Leumann 1907: 108] вариантом вед. глаг. gr্--, grnăti ‘взывать, славить, восхвалять’ и, таким образом, одинаково может быть возведён и к и.-е. * $g e r-$ и к * $g^{w} \operatorname{er}(\partial)-$. Примечателен кажущийся параллелизм слав. оппозиции *žerti, *žbretb 'приносить жертву': *žbrati, *žbretb 'жрать, жрёт, поедать’ (омофоны?) и др.-инд. j’̣--, járate; gr̆-, grnăti ‘взывать, восхвалять’: $j \bar{r}-$-, jarayati (кауз.) 'потреблять, переваривать': gr্--, girati 'глотать, есть, пожирать' (в последнем случае лучше заметны словообразовательные и словоизменительные различия). Идея родства этого глагола с глаг. жрать и принадлежности аналогическому ряду $*_{z ̌ b r t i ~}$ *žbrati (как *pěti * * piti) более чем сомнительна. Но само это явление продолжает смущать некоторых этимологов и наводит их на мысль о гомогенности и.-е. глаголов, ведь и крик, и восхваление, и глотание связаны с горлом (и.-е. * $g^{w}$ erz-). При этом акт жертвоприношения мог восприниматься как поглощение подношения божеством и тесно связываться с громкими призывами и песнопениями. Это всего лишь гипотеза, основанная на гипотезе и отягощенная опытом позднейших времен. Ведь ранняя стадия поклонения божествам у большинства примитивных народов была благоговейной, безмолвной (без призывания имён, песнопений или чего-л. подобного) [Токарев 1990 : 376-403].

Русск. жертва (праслав. *žbrbtva) др.-инд. jaritvā

В русск. словесности XI-XVII вв. изв. жьртва (наряду с цслав. жрътва), позже жертва; прилаг. жьртвьнь, жьртвьныи, жертвеньныи; глаг. жертвовать отм. в словарях с 1704 г. Восходит к праслав. *žbrbtva, производному с суф. -btva от корня *žbr- глаг. *žbrěti, *žbrQ 'приносить в жертву, совершать жертвоприношение', продолжающего и.-е. * $g^{w} e r(\partial)-: *^{*} r(\partial)-$ 'восхвалять, превозносить, взывать' [Pokorny 478]. Ср. жреть, жрец.

Др.-инд. jaritvā производно с суф. -t-vā от основы глаг. grnăti ‘воспевает, превозносит, восхваляет' и сущ. gitr ж. 'хвала, награда', дополняется авест. глаг. $\bar{a} y a i r y \overrightarrow{a t}$ ‘превозносится' и сущ. gar ж. 'хвала, награда, хвалебная песнь'. Все они продолжают и.-е. глаг. * $g^{w} e r(\partial)-: *^{*} g_{o}^{w}(\partial)-$ 'восхвалять, превозносить, взывать' [Pokorny 478]. Ср. словообразовательную модель с дентальным расширителем основы лат. grātēs мн. 'благодарность'. Русск. форма отличается от санскр. ступенью огласовки корня.

Др.-русск. жиръ, жьръ (праслав. *žirъ, *žbrъ) др.-инд. gǐr, gír

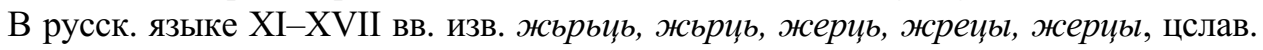
жьрьиь [СлРЯ XI-XVII вв. 5: 123, 126] дополняются именными основами имён-композитов младшей серии жир-о- и -жирь, -жьрь 'жертвоприношение, жречество, жреческое служение, хвала, восхваление; жрец, жреческое сословие’: (Bъ)зда(u) жиръ, (Въ)зда(и)жьрь [Васильев 2012: 232, 246, 251, 252, 667]; Горижиръ, гипокористика Горижа [Васильев 2012: 558]; Гостижиръ, гипокористики Гостижь, Гостижа, Гастижа, Гостижка, Гастышка [Васильев 2012: 557, 558, 559, 674]; 
Доброжиръ [Васильев 2012: 108, 730]; Доможиръ, Домажиръ, Домъжиръ [Васильев 2012: 74, 78, 246, 252]; Дорогожиръ, гипокористика Дорогожа [Васильев 2012: 192, 163, 164, 192]; Жиробждъ, гипокористики Жир Ата, Жир Атъка [Васильев 2012: 252, 311, 320]; Жирогость [Васильев 2012: 172, 192]; Жиромиръ, гипокористика Жирома [Васильев 2012: 325, 676]; Жиронъгъ [Васильев 2012: 98, 99, 681, 730]; Жирославъ [Васильев 2012: 84, 85, 87, 252, 312, 669, 670, 730], гипокористики ЖирАта, Жир Атъка [Васильев 2012: 252, 311, 324], Жирята [Тупиков]; Жьдажьрь [Васильев 2012: 251, 667]; (И)здажсиръ, Издажьръ [Васильев 2012: 232, 246, 251, 252, 667]; Любожиръ, Любъжиръ, Любежиръ, гипокористика Любож Ата (?) [Васильев 2012: 319, 561, 562, 673, 676]; Людижьръ, Людожьръ, Людожер, Людожор [Васильев 2012: 231, 232, 252, 669]; Об(на)жиръ, По(на)жьрь, Пажьрь [Васильев 2012: 611, 674]; Ст(ан)ижиръ, стяжение в Стежира [Зализняк 2004: 5, 803]; Тужиръ [Васильев 2012: 85, 232, 246, 251, 252, 253, 614] на основе словосочетания ту жьреть; Чебожирь [Васильев 2012: 319]; Щежьрь [Васильев 2012: 186]. Именная основа жиро-, -жирь отвлечена от прецедентного диал. итеративного глаг. жирати, жираю или жирвти, жиръю по глаг. жер(е)ти, жьрти, жьрю 'совершать жертвоприношение; хвалить, восхвалять', омофона лучше известного другого др.-русск. глаг. обжирати, обжирвти, обжирити [ЭССЯ 31: 251-252]; иначе можно трактовать праслав. сущ. *žirb как результат регулярного продления корневого вокализма в глаг. основе *žbrti 'совершать жертвоприношение; восхвалять', возводимой к и.-е. * $g^{w}$ er(ә)- 'поднимать голос, славить' [Pokorny 478] или к и.-е. экспрессивному *ger(ә)- 'пронзительно кричать'. Ср. др.-прусск. pogirrien вин. 'хвала', лат. grātēs мн. 'благодарность'.

Др.-инд. сущ. gir (в словосложении gir $)$ ж. 'хвала, награда' дополняется авест. сущ. gar ж. 'хвала, награда, хвалебная песнь' и является однокоренным вед. глаг.

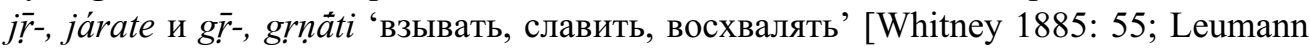
1907: 108; Mayrhofer I: 421] и одинаково может быть отнесено и к и.-е. *ger-, и к * $g^{w} e r(\partial)-$ К. Как и в случае с глаг. жреть и жрать, праслав. диал. сущ. *žirz, *žbrb 'хвала, восхваление, принесение в жертву' является омофоном праслав. *žirb 'жир'. Тут коренится ложная идея гомогенности этих сущ., так как и крик, и восхваление, и жертвенный тук, и глотание оказываются связаны с горлом (и.-е. * $g^{w} e r-$ ). При этом акт жертвоприношения, якобы, мог восприниматься как поглощение подношения божеством и тесно связываться с громкими призывами и песнопениями. Это всего лишь гипотеза, отягощенная опытом позднейших времен. Ведь ранняя стадия поклонения божествам у большинства примитивных народов была благоговейной, безмолвной (без «горлового пения», призывания имён, песнопений, восхвалений или чего-л. подобного). Идея этимологического родства двух сущ. *žirъ I и *žirъ II более чем сомнительна.

\section{Литература}

Борисов К. Л. (Constantine Leo Borissoff, Birbeck, University of London, Applied Linguistics and Communication, Alumnus) Опыт создания словаря общих и родственных слов русского и санскрита // Материалы IX Чтений памяти академика 
РАН О.Н. Трубачёва. Сборник научных статей / Сост. и науч. ред. А. К. Шапошников. - М.: Институт русской цивилизации, 2015. - 103 с.

Васильев В.Л. Славянские топонимические древности Новгородской земли. М.: Рукописные памятники Древней Руси, 2012. — 816 с. — (1150 лет российской государственности).

Грошева А. В. «Индоевропейское наследие в латинских названиях деревьев» // Hridă mánasā. Сборник статей к 70-летию со дня рождения профессора Л. Г. Герценберга. Отв. ред. Н.Н. Казанский. СПб.: Наука, 2005. - сс. 250-275.

Даль В.И. Толковый словарь живого великорусского языка. 2 изд. СПб.; М.., 1880-1882 (1955). T. I-IV.

Мельничук, А.C. Корень *kes- и его разновидности в лексике славянских и других индоевропейских языков // Этимология. 1966, М.: «Наука», 1968, 194-240.

Мартынов В.В. Славяно-германское лексическое взаимодействие древнейшей поры. Минск, 1963.

Носович И. И. Словарь белорусского наречия. СПб., 1870.

Сердюкова E.B. Ономасиологический аспект праславянских фитонимов // Международная конференция «Северное Причерноморье: к истокам славянской культуры» (5 Чтения памяти академика О.Н. Трубачёва), Алупка, 25-30 сентября 2008 г. Материалы конференции. - Киев; М., 2008. 143-147.

Срезневский И. И. Материалы для Словаря древнерусского языка. Т. I-III. СПб., 1893-1903.

Токарев С.А. Ранние формы религии. М.: Политиздат, 1990

Топоров В.Н. Фрак. Spártakos в индоевропейском контексте // Onomstica Jugoslavica. Vol. 9. Zbornik radova u čast akademiku Francetu Bezlaju o sedamdesatoj obljetnici života. Zagreb, 1982. S. 145-157;

Топоров В.Н. Фрак. Spártakos в индоевропейском контексте // Исследования по этимологии и семантике. Т. 2: Индоевропейские языки и индоевропеистика. н. 1. - М.: Языки славянских культур, 2006. - 544 с. 283-296;

Трубачёв О.Н. Indoarica в Северном Причерноморье. М.: Наука, 1999.

Трубачёв О.Н. История славянских терминов родства и некоторых древнейших терминов общественного строя. М., 1959.

Трубачёв О.Н. Серебро // Восточнославянское и общее языкознание. М., 1978, c. $95-102$.

Трубачёв О.Н. Этногенез и культура древнейших славян. Лингвистические исследования. Изд. второе, доп. М., 2002.

Тупиков Н.М. Словарь древнерусских личных собственных имен. СПб., 1903. Н.М. Тупиков. Словарь древнерусских личных собственных имен. М., 2004.

Фасмер М. Этимологический словарь русского языка. Перевод с немецкого и дополнения О.Н. Трубачёва, т. I. М., 1964; т. II — 1967; т. III — 1971; т. IV 1973.

Черных П.Я. Историко-этимологический словарь современного русского языка. Изд. 2, стереотипное. М., 1994. Т. I-II. 
Шапошников А. К. Языковые реликты фракийского облика в Северном Причерноморье // Этимология 2009-2011 / Отв. ред. Ж.Ж. Варбот; Ин-т рус.яз.им. В. В. Виноградова РАН. - М.: Пробел-2000, 2012. - сc. 252-308.

Шапошников $A . K$. Лексический комплекс пеласгического вида в праславянском // Studia etymologica Brunensia 6 / Editorky: Ilona Janyšková, Helena Karlíková. Praha, Nakladatelství Lidové noviny, 2009, 303-311;

Шапошников А.К. Праславянское лексическое гнездо с нерегулярными чередованиями производящей основы: *torp-, *tbrp-, *trup- // Словенска етимологија данас. Зборник симпозијума одржаног од 5. до 10. септембра 2006. године. - Београд, 2007. - СС. 431-435.

Шапошников А. К. Русско-санскритский словарь общих и родственных слов предварительные результаты электронной сравнительно-сопоставительной лексикографии // VII Международная научная конференция «Русский язык в языковом и культурном пространстве Европы и мира: человек, сознание, коммуникация, интернет». 6-10 мая 2016 года, посвященная 200-летию основания Варшавского Университета. Warszawa, 2017.

Шахматов А. Очерк древнейшего периода истории русского языка // Энц. Слав. Филол., т. ХІ, Спб., 1915. Очерк 153.

Bartholomae Chr. Altiranisches Wörterbuch. Straßburg, 1904.

Derksen R. Etymological Dictionary of the Slavic Inherited Lexicon. Leiden • Boston, 2008.

Falk H., Torp A. Norwegisch-dänisches etymologisches Wb, 2 Bde, Heidelberg, 1910-1911

Falk H., Torp A. Wortschatz der germanischen Spracheinheit. 5, unveränd. Aufl. Göttingen, 1979.

Friedrich P. Structural implications of Russian Pronominal Usage // Sociolinguistics. Proceedings of the UCLA Sociolinguistics Conference, 1964, The Hague - Paris, 1966, 214-253.

Hesychius 1867: 892

Indeks a tergo do Materiałów do Słownika języka staroruskiego I. I. Srezniewskiego / pod kierukiem Antoniny Obrębskiej-Jabłońskiej. Warszawa: Panstwowe wydawnictwo naukowe, 1968

Kloekhorst A. Etymological Dictionary of the Hittite Inherited Lexicon Brill Academic Publishers, 2008.

Korotayev A. Return of the White Raven: Postdiluvial Reconnaissance Motif A2234.1.1 Reconsidered. Journal of American Folklore 119 (2006): 472-520.

Latte, Kurt [ed.]. Hesychii Alexandrini Lexicon. Vol. I-II. Hauniae: Ejnar Munksgaard. 1953-1966.

Leumann E., Leumann J. Indica. Etymologisches Wb. Lpzg: O. Harassowitz, 1907.

Lewy E. Slav. vina. Mélanges de philologie offerts à M. J. J. Mikkola ... á l'occasion de son soixante-cinquième anniversaire, le 6 juillet 1931, Helsinki: Suomalainen Tiedeakatemia, 1931: 114. 
Machek $V$. Die slawischen und baltischen Entsprechungen der lateinischen Intensivverba auf -tāre und -sāre // Zeitschrift für Slawistik, Band 25, 1980, 53-61.

Machek V. Max Vasmer: Russisches etymologisches Wörterbuch. Zweiter Band $(L-$ ssuda). Heidelberg (Winter) 1955, 712 S. — Dritter Band (-sta - jaščur). 1958, 697 S. // Slavia 28 (1959), 271.

MacKenzie D.N. A concise Pahlavi dictionary. London: Oxford University Press, 1986.

Mayer A. Die Sprache der alten Illyrier, Bd. I-II. Wien, 1957-1959.

Mayrhofer M. Etymologisches Wörterbuch des Altindoarischen. Heidelberg, 1986. B. 1, Lief. 1. Oriens. Leiden.

Monier-Williams M. A Sanskrit-English dictionary etymologically and philologically arranged with special reference to cognate Indo-European languages. New edition, greatly enlarged and improved. Oxford, 1964; M. Monier-Williams. A dictionary English and Sanskrit, Reprinted by photoprocess from the edition of 1851. Published by W.H. Allen, London. Delhi — Varanasi — Patna, 1956.

Pakerys J. Konferencija „Baltų kalbų etimologija ir onomastika“ Sankt Peterburge Baltistica, 2002, 37, 93-195.

Palionis J. Lettizismen in Bretkūnas Wortschatz Symposium Balticum: A festschrift to honour professor Velta Rūķe-Dravina, H. Buske, 1990: 355-359.

Pokorny J. Indogermanisches etymologisches Wörterbuch. Bd. I-II. Bern, 1949-1959.

Pudić I. Die Sprache der alten Makedonen // Studia Balcanica V. l'ethnogenèse des peuples balcaniques. - Sofia: Institut d'études balcaniques, 1971. - 207-223.

Russian-Sanskrit Dictionary of Common and Cognate Words Русско-санскритский словарь общих и родственных слов / Constantin Leo Borissoff, Alexander C. Shaposhnikov, London, 2015. [https://dict.gir.me.uk/words/2503/]

Schmidt J. Die Pluralbildungen der indogermanischen Neutra. Weimar, 1889.

Skok $P$. Etimologijski rječnik hrvatskoga ili srpskoga jezika. Bd. I-IV. Zagreb, 19711974.

Sławski F. Słownik etymologiczny języka polskiego. Kraków, 1952-1983. T. 1-5.

Stankiewicz E. The Etymology of Common Slavic *vъnokъ / *vъnukъ // The Slavic and East European Journal, American Association of Teachers of Slavic and East European Languages, 1962, №6, 28-33.

Whitney $W$. The Roots, Verb-Forms, and Primary Derivatives of the Sanskrit Language (supplement to Sanskrit Grammar). Leipzig: Breitkopf and Härtel, 1885.

\section{Сокращения}

БЕР - Български етимологичен речник / Съст. Георгиев В., Гълъбов Ив., Заимов Й., Илчев Ст. и др. София, 1962-2017-. Т. I-VIII-.

Буга // РФВ 75 - Буга К. // Русский Филологический Вестник, № 75, Варшава, 1914.

Бялькевіч. Магіл. - Бялькевіч I. К. Краёвы слоўнік усходняй Магілёўшчыны. Мінск, 1970.

Евгеньева - Словарь русского языка. В 4-х т. / Ред. А. Л. Евгеньева. М., 1999. 
Младенов ЕПР - Младенов $C$. Етимологически и правописен речник на българския книжовен език. София, 1941.

ПОС - Псковский областной словарь с историческими данными. Под. ред. $\dagger$ Б. А. Ларин, А. С. Герд, С. М. Глускина, † И. Т. Гомонов, Л. А. Ивашко, А. И. Корнев, А.И. Лебедева, О. С. Мжельская, Вып. 3. в - взяться. 1976;

РФВ - Русский Филологический Вестник, основ. В. Колосов. 78 тт., Варшава, 1879-1918.

САР - Словарь Академии Российской 1789-1794: В 6 т. М., 2001-2007. Т. 1-6.

СДРЯ (XI-XIV вв.) - Словарь древнерусского языка (XI-XIV вв.) / Гл. ред. чл.-кор. АН СССР Р.И. Аванесов; V Р.И. Аванесов, дфн И.С. Улуханов; ХІ дфн В.Б. Крысько. М., 1988-1989-1990-1991-2000-2002-2004-..-2012-20132016- - продолж. T. I-II-III-IV-V-VI-VII-VIII-IX-X-XI - продолж.

СлРЯ XI-XVII вв. - Словарь русского языка XI-XVII вв. Составители: Н. Б. Бахилина, Г.А. Богатова, Е. Н. Прокопович и др. Главный редактор С. Г. Бархударов, Г. А. Богатова и др. Вып. 1-30 - продолж., М., 1975-2015 - продолж.

СлРЯ XI-XVII вв. Справ. Вып. - Словарь русского языка XI-XVII вв. Справочный выпуск / Ин-т рус. яз. им. В. В. Виноградова РАН. - М.: Наука, 2001. — 814 с.

СлРЯ XVIII в. - Словарь русского языка XVIII века. Л. (с 7 вып. Спб.): Наука, 1984-2015-. Вып. 1-21- (до помощный).

СРНГ - Словарь русских народных говоров / Под ред. Ф. П. Филина, Ф.П. Сороколетова, С. А. Мызникова. - М., Л., 1965-2017-. Вып. 1-50-.

Тураўскі сл. / Крывіцкі и др. - Тураўскі слоўнік. Складальн. А.А. Крывіцкі, Г. А. Цыхун, І.Я. Яшкін. 1-2 - . Мінск, 1982-.

Ушаков - Толковый словарь русского языка / Под ред. Д.Н. Ушакова: В 4 т. M., 1935-1940.

AfslPh - Archiv für slavische Philologie, begründet von V. Jagić, Berlin 1876-1929

BB - Beiträge zur Kunde der Indogermanischen Sprachen. Hrsg. A. Bezzenberger. 1-30 . Göttingen 1877-1906.

Boryś SEJP — Boryś $W$. Słownik etymologiczny języka polskiego. Kraków, 2005.

BSL - Bulletin de la Société de linguistique de Paris.

Hujer // LF, 1933, LX, 473-474 - Hujer O. Mélanges de philologie offerts a M. J. J. Mikkola // Listy filologické, 1933, 60, 472-474.

IF - Indogermanische Forschungen, Zeitschrift für Indogermanistik und allgemeine Sprachwissenschaft. Strassburg - Berlin.

Kralik SESS - Králik L'ubor. Stručný etymologický slovník slovenčiny Bratislava: VEDA, 2015.

KZ - Zeitschrift für vergleichende Sprachforschung auf dem Gebiete der indogermanischen Sprachen, begr.v. A. Kuhn. Berlin — Güttersloh — Göttingen 1852 -

LF — Listy filologické, Praha 1874 nn.

Machek ESJČaS - Machek $V$. Etymologický slovník jazyka českého a slovenského. Praha, 1957.

Meillet // BSL 29 - Meillet Antoine // Bulletin de la Société de linguistique de Paris n. 29. 
Meillet // IF 5 - Meillet Antoine // Indogermanische Forschungen, Zeitschrift für Indogermanistik und allgemeine Sprachwissenschaft $n$. 5. Strassburg - Berlin.

Meillet // MSL 8; 10 - Meillet Antoine // Mémoires de la Société de linguistique de Paris nn. 8, 10.

Meillet // RS 3 - Meillet Antoine // Rocznik Slawistyczny n. 3. Wrocław Kraków - Warszawa.

Meillet EAM - Meillet Antoine Esquisse d'une grammaire comparée de l'arménien classique. P., 1903.

Meillet Études. - Meillet Antoine. Études sur l'étymologie et le vocabulaire du vieux slave, I-II. Paris, Bouillon. 1902, 1905.

Mikkola // RS 1 - Mikkola J. J. // Rocznik Slawistyczny n 1. Wrocław — Kraków Warszawa.

Mikkola // BB 22 - Mikkola J.J. // Beiträge zur Kunde der Indogermanischen Sprachen. Hrsg. A. Bezzenberger. N 22 (1898). Göttingen.

Mikkola Urslav. Gramm. - Mikkola J.J. Urslavische Grammatik. 1. Teil. 1913, 2. Teil. 1942, 3. Teil. 1950, Heidelberg.

Mladenov St. Aind. ambhrnás // KZ 44 - Mladenov St. Altindisches ambhrnás (амфора) // Zeitschrift für vergleichende Sprachforschung auf dem Gebiete der indogermanischen Sprachen, begr. v. A. Kuhn. Berlin — Güttersloh — Göttingen, № 44, 1896.

MSL - Mémoires de la Société de linguistique de Paris.

Pāṇini 6-4, 157 - Pāṇini's Grammatik, hrsg. von O. Böhtlingk, Leipzig, 1887.

Pedersen // KZ 38 - Pedersen H // Zeitschrift für vergleichende Sprachforschung auf dem Gebiete der indogermanischen Sprachen, begr. v. A. Kuhn. Berlin - Güttersloh Göttingen, XXXVIII, 1890-395.

Rejzek ČEJ — Rejzek J. Český etymologický slovník. Voznice, 2001.

RÉS - Revue des études slaves, Paris, 1921-.

RS - Rocznik Slawistyczny. Wrocław - Kraków - Warszawa

Trautmann // AfslPh 38 - Trautmann R. // Archiv für slavische Philologie, begründet von V. Jagić, Berlin XXXVIII, 1914, 130

Trautmann Apr. Sprd. - Die Altpreußischen Sprachdenkmäler von R. Trautmann, t. 1-2, Göttingen, 1909-1910.

Trautmann BSW - Trautmann R. Baltisch-slavisches Wörterbuch. Göttingen, 1923.

Vaillant // RÉS XI — Vaillant A. // Revue des études slaves, Paris, XI, 1932: 206.

Watkins IER - The American Heritage' Dictionary of Indo-European Roots. 2nd Edition, revised and edited by Calvert Watkins. Boston, New York: Houghton Mifflin Company, 2000. 
Constantine Leo Borissoff

Birbeck, University of London, Applied Linguistics and Communication, Alumnus

A. C. Shaposhnikov

Vinogradov Russian Language Institute of the Russian Academy of Sciences

(Russia, Moscow)

etymol@mail.ru

\section{RUSSIAN-SANSKRIT ETYMOLOGICAL SKETCHES}

The article reported some results, interesting for the Russian etymology, of the recent lexicographical project of C. L. Borissoff and A. C. Shaposhnikov [Russian-Sanskrit Dictionary of Common and Cognate Words], implemented in 2015-2016. In the process of compiling this dictionary, the co-authors found many new instances of Sanskrit-Russian isoglosses, which were in disregard by comparativists of the past. Some common word formation and derivation models were reveled. Etymologies for some Russian and Sanskrit words are updated or revised. In some cases it was possible to reconstruct the semantic history of words, to outline the primary meanings and to trace the evolution of semantics. These etymological sketches cover a part of Common Slavonic vocabulary from P to $\check{Z}$ that is of interest to us.

Key words: comparison, isoglosses, archetype, reconstruct, etyma, semantics, word formation, IE root, IE base, prefix, infix, suffix, theme, variant, allomorph, omophone, etymology.

\section{References}

Borissoff C.L. Opyt sozdaniya slovarya obshchikh i rodstvennykh slov russkogo $i$ sanskrita [An Essay at Creating a Dictionary of Common and Cognate Words in Sanskrit and Russian]. Proceedings of the 9th Readings in Memory of RAS Academician O.N. Trubachev / Compiled and edited by A.K. Shaposhnikov. - Moscow: Institut russkoi tsivilizatsii Publ., 2015. - 103 p.

Vasil'ev V.L. Slavyanskie toponimicheskie drevnosti Novgorodskoi zemli [Slavic Toponymic Antiquities of the Novgorod Land]. Moscow: Rukopisnye pamyatniki Drevnei Rusi Publ., 2012. - 816 p.

Grosheva A. V. Indoevropeiskoe nasledie v latinskikh nazvaniyakh derev'ev [IndoEuropean Heritage in Latin Plant names]. Hrdá mánasāa. Papers in Commemoration of L. G. Gertsenberg's $70^{\text {th }}$ birthday. Ed by N. N. Kazanskii. Saint Petersburg: Nauka Publ., 2005. - pp. 250-275.

Dal' V.I. Tolkovyi slovar' zhivogo velikorusskogo yazyka [Interpretative Dictionary of the Live Russian Language]. 2nd edition. Saint Petersburg; Moscow, 1880-1882 (1955). Vols. I-IV.

Martynov V.V. Slavyano-germanskoe leksicheskoe vzaimodeistvie drevneishei pory [Slavic-Germanic Lexical Interactions of The Earliest Period]. Minsk, 1963. 
Mel'nichuk A. S. Koren' *kes- i ego raznovidnosti v leksike slavyanskikh i drugikh indoevropeiskikh yazykov [The Root *kes- and Its Varieties in Slavic and Other Indo-European Vocabularies]. Etimologiya 1966, Moscow: Nauka Publ., 1968, 194-240.

Nosovich I.I. Slovar' belorusskogo narechiya [Dictionary of the Belarusian Language]. $\mathrm{SPb} ., 1870$.

Serdyukova E. V. Onomasiologicheskii aspekt praslavyanskikh fitonimov [The Onomasiological Aspect of Proto-Slavic Plant Names]. International conference «Severnoe Prichernomor'e: $k$ istokam slavyanskoi kul'tury» [Northern Black Sea Region: To the Origins of Slavic Culture] (5th Readings in Memory of Academician O. N. Trubachev), Alupka, 25-30 September 2008. Proceedings. - Kiev; Moscow, 2008. 143-147.

Sreznevskii I. I. Materialy dlya Slovarya drevnerusskogo yazyka [Materials for the Dictionary of the Old Russian language]. Vols. I-III. Saint Petersburg, 1893-1903.

Tokarev S. A. Rannie formy religii [Earliest Forms of Religion]. Moscow: Politizdat Publ., 1990.

Toporov V. N. Frak. Spártakos v indoevropeiskom kontekste [Thracian Spártakos in the Indo-European Context]. Onomstica Jugoslavica. Vol. 9. Zbornik radova u čast akademiku Francetu Bezlaju o sedamdesatoj obljetnici života. Zagreb, 1982. P. 145-157.

Toporov V.N. Frak. Spártakos v indoevropeiskom kontekste [Thracian Spártakos in the Indo-European Context]. Issledovaniya po etimologii i semantike. Volume 2: Indoevropeiskie yazyki i indoevropeistika [Studies in Etymology and Semantics. Volume 2. Indo-European Languages and Subject Matters]. n. 1. — Moscow: Yazyki slavyanskikh kul'tur Publ., 2006. - 544 p. 283-296.

Trubachev O.N. Indoarica v Severnom Prichernomor'e [Indoarica in the Northern Black Sea Region]. Moscow: Nauka Publ., 1999.

Trubachev O.N. Istoriya slavyanskikh terminov rodstva i nekotorykh drevneishikh terminov obshchestvennogo stroya [History of the Slavic Kinship Terms and Some of the Oldest Social Order Related Vocabulary]. Moscow, 1959.

Trubachev O.N. Serebro [Silver]. Vostochnoslavyanskoe i obshchee yazykoznanie [East Slavic and General Linguistics]. Moscow, 1978, p. 95-102.

Trubachev O. N. Etnogenez i kul'tura drevneishikh slavyan. Lingvisticheskie issledovaniya [Ethnogenesis and Culture of the Ancient Slavs. Linguistic Explorations]. $2^{\text {nd }}$ edition, augm. Moscow, 2002.

Tupikov N. M. Slovar' drevnerusskikh lichnykh sobstvennykh imen [Dictionary of Old Russian Personal Names]. Saint Petersburg, 1903. N. M. Tupikov. Slovar' drevnerusskikh lichnykh sobstvennykh imen. Moscow, 2004.

Fasmer M. Etimologicheskii slovar' russkogo yazyka [Etymological Dictionary of the Russia Language]. Translated from German and augmented by O. N. Trubachev, vol. I. Moscow, 1964; vol. II - 1967; vol. III - 1971; vol. IV - 1973.

Chernykh P. Ya. Istoriko-etimologicheskii slovar' sovremennogo russkogo yazyka [Historical-Etymological Dictionary of the Russian Language]. $2^{\text {nd }}$ edition, stereot. Moscow, 1994. Vols. I-II.

Shaposhnikov A. K. Yazykovye relikty frakiiskogo oblika v Severnom Prichernomor'e [Lingustic Relics Appearing to be Thracian in the Northern Black Sea Region]. 
Etimologiya [Etymology] 2009-2011, Ed. Zh. Zh. Varbot; V.V. Vinogradov Russian Language Institute RAS. Moscow: Probel-2000 Publ., 2012. — p. 252-308.

Shaposhnikov A.K. Leksicheskii kompleks pelasgicheskogo vida v praslavyanskom [A Lexical Complex Appearing to be of Pelasgian Origin in Proto-Slavic]. Studia Etymologica Brunensia 6 / Eds.: Ilona Janyšková, Helena Karlíková. — Praha: Lidové noviny Publ., 2009, 303-311.

Shaposhnikov A. K. Praslavyanskoe leksicheskoe gnezdo s neregulyarnymi cheredovaniyami proizvodyashchei osnovy: *torp-, *t'rp-, *trup- [Proto-Slavic Lexical Family with Irregular Alternations of the Basic Stem *torp-, *t'rp-, *trup-]. Slovenska etimologija danas [Slavic Etymology Today]. Proceedings of the symposium held on 5-10 September 2006. - Beograd, 2007. - pp. 431-435.

Shaposhnikov A.K. Russko-sanskritskii slovar' obshchikh i rodstvennykh slov predvaritel'nye rezul'taty elektronnoi sravnitel'no-sopostavitel'noi leksikografii [A Russian-Sanskrit Dictionary of Shared and Related Vocabulary - Preliminary Results of Electronic Comparative Lexicographis Research]. VII International Conference «Russkii yazyk v yazykovom i kul'turnom prostranstve Evropy i mira: chelovek, soznanie, kommunikatsiya, internet» [The Russian Language in the Linguistic and Cultural Space of Europe and the World: Human, Consciousness, Communication, the Internet]. 6-10 May 2016, dedicated to the $200^{\text {th }}$ anniversary of the foundation of Warsaw University. Warszawa, 2017.

Shakhmatov A. Ocherk drevneishego perioda istorii russkogo yazyka [An Outline of the Earliest Period in the History of The Russian Language]. Ents. Slav. Filol., t. XI, Spb., 1915. Ocherk 153.

Bartholomae Chr. Altiranisches Wörterbuch [Old Iranian Etymological Dictionary]. Straßburg, 1904.

Derksen R. Etymological Dictionary of the Slavic Inherited Lexicon. Leiden • Boston, 2008.

Falk H., Torp A. Norwegisch-dänisches etymologisches Wb, 2 Bde [Norwegian-Danish Etymological Dictionary, in 2 volumes]. Heidelberg, 1910-1911.

Falk H; Torp A. Wortschatz der germanischen Spracheinheit [Lexical Stock of the Germanic Linguistic Unity]. 5, unveränd. Aufl. Göttingen, 1979.

Friedrich P. Structural implications of Russian Pronominal Usage. Sociolinguistics. Proceedings of the UCLA Sociolinguistics Conference, 1964, The Hague - Paris, 1966, 214-253.

Hesychius 1867: 892.

Indeks a tergo do Materiałów do Stownika języka staroruskiego I. I. Srezniewskiego [An a tergo Index for the Materials for I.I. Sreznevsky's Dictionary of the Old Russian Language] / under guidance of Antonina Obrębska-Jabłońska. Warszawa: Panstwowe wydawnictwo naukowe, 1968.

Kloekhorst A. Etymological Dictionary of the Hittite Inherited Lexicon. Brill Academic Publishers, 2008.

Korotayev A. Return of the White Raven: Postdiluvial Reconnaissance Motif A2234.1.1 Reconsidered. Journal of American Folklore 119 (2006): 472-520. 
Latte Kurt [ed.]. Hesychii Alexandrini Lexicon. Vol. I-II. Hauniae: Ejnar Munksgaard. 1953-1966.

Leumann E., Leumann J. Indica. Etymologisches $W b$. [Indica. Etymologial Dictionary]. Leipzig: O. Harassowitz, 1907.

Lewy E. Slav. vina ['guilt']. Mélanges de philologie offerts à M.J. J. Mikkola ... á l'occasion de son soixante-cinquième anniversaire, le 6 juillet 1931 [Philological Miscellanea Presented to M. J.J. Mikkola on the Occasion of His Sixty-Seventh Birthday, July 6, 1931], Helsinki: Suomalainen Tiedeakatemia, 1931: 114.

Machek V. Die slawischen und baltischen Entsprechungen der lateinischen Intensivverba auf -tāre und -sāre. Zeitschrift für Slawistik, Band 25, 1980, 53-61.

Machek V. Max Vasmer: Russisches etymologisches Wörterbuch. Zweiter Band (L - ssuda) [Max Vasmer: Russian Etymological Dictionary. Second Volume ( $L-$ ssuda)]. Heidelberg (Winter) 1955, 712 p. — Dritter Band (-sta - jaščur). 1958, 697 p. Slavia 28 (1959), 271.

MacKenzie D. N. A concise Pahlavi dictionary. London: Oxford University Press, 1986.

Mayer A. Die Sprache der alten Illyrier [Language of the Ancient Illyrians], Bd. I-II. Wien, 1957-1959.

Mayrhofer M. Etymologisches Wörterbuch des Altindoarischen [Etymological Dictionary of Indo-Aryan]. Heidelberg, 1986. B. 1, Lief. 1. Oriens. Leiden.

Monier-Williams M. A Sanskrit-English dictionary etymologically and philologically arranged with special reference to cognate Indo-European languages. New edition, greatly enlarged and improved. Oxford, 1964; M. Monier-Williams. A dictionary English and Sanskait, Reprinted by photoprocess from the edition of 1851. Published by W. H. Allen, London. Delhi - Varanasi — Patna, 1956.

Pakerys J. Konferencija „Baltu kalbu etimologija ir onomastika“ Sankt Peterburge [Conference «Baltic Etymology and Onomastics» in Saint Petersburg]. Baltistica, 2002, 37, 93-195.

Palionis J. Lettizismen in Bretkūnas Wortschatz [Latvian Elements in the Bretkūnas Lexicon]. Symposium Balticum: A festschrift to honour professor Velta Rūķe-Draviṇa, H. Buske, 1990: 355-359.

Pokorny J. Indogermanisches etymologisches Wörterbuch [Indo-European Etymological Dictionary]. Bd. I-II. Bern, 1949-1959.

Pudić I. Die Sprache der alten Makedonen [The Language of the Ancient Macedonians]. Studia Balcanica V. L'ethnogenèse des peuples balcaniques [Balcanic Studies 5. Ethnogenesis of the Balkanic Peoples]. — Sofia: Institut d'études balcaniques, 1971. pp. 207-223.

Russian-Sanskrit Dictionary of Common and Cognate Words. Constantin Leo Borissoff, Alexander C. Shaposhnikov, London, 2016. [https://dict.gir.me.uk/words/2503/]

Schmidt J. Die Pluralbildungen der indogermanischen Neutra [Plural Formations of the Indo-European Neutra]. Weimar, 1889.

Skok P. Etimologijski rječnik hrvatskoga ili srpskoga jezika [Etymological Dictionary of the Croatian, or Serbian, Language]. Bd. I-IV. Zagreb, 1971-1974. 
Sławski F. Stownik etymologiczny jezzyka polskiego [Etymological Dictionary of the Polish Language]. Kraków, 1952-1983. Vol. 1-5.

Stankiewicz E. The Etymology of Common Slavic *vъnekb / *vъnukb //. The Slavic and East European Journal, American Association of Teachers of Slavic and East European Languages, 1962, No. 6, 28-33.

Whitney W. The Roots, Verb-Forms, and Primary Derivatives of the Sanskrit Language (supplement to Sanskrit Grammar). Leipzig: Breitkopf and Härtel, 1885.

Abbreviations

BER - Bălgarski etimologichen rechnik [Bulgarian Etymological Dictionary] / Copiled by Georgiev V., Gălăbov Iv., Zaimov I., Ilchev St. et al. Sofia, 1962-2017-. T. IVIII-.

Buga // RFV 75 - K. Buga // Russkii Filologicheskii Vestnik [Russian Philological Bulletin], № 75, Warsaw, 1914.

Byal'kevich. Magil. — I.K. Byal'kevich. Kraevy sloünik uskhodnyai Magileŭshchyny [Local Dictionary of the Eastern Mogilyov Region]. Minsk, 1970.

Evgen'eva - Slovar' russkogo yazyka [Dictionary of the Russian Language]. In 4 volumes. / Ed. by A. L. Evgen'eva. Moscow, 1999.

Mladenov EPR - S. Mladenov. Etimologicheski i pravopisen rechnik na bălgarskiya knizhoven ezik [Etymological and Orthographical Dictionary of the Literary Bulgarian Language]. Sofia, 1941.

POS - Pskovskii oblastnoi slovar's istoricheskimi dannymi [Pskov Regional Dictionary with Historical Data]. Ed by. $\uparrow$ B. A. Larin, A. S. Gerd, S. M. Gluskina, $\uparrow$ I. T. Gomonov, L.A. Ivashko, A.I. Kornev, A. I. Lebedeva, O. S. Mzhel'skaya, Iss. 3. v vzyat'sya. 1976;

RFV - Russkii Filologicheskii Vestnik [Russian Philological Bulletin], founded by V. Kolosov. 78 vols., Warsaw, 1879-1918.

SAR - Slovar' Akademii Rossiiskoi [Dictionary of the Russian Academy] 17891794: In 6 vols. Moscow, 2001-2007. T. 1-6.

SDRYa (XI-XIV vv.) - Slovar' drevnerusskogo yazyka (XI-XIV vv.) [Dictionary of the Old Russian Language (11-14 ${ }^{\text {th }}$ centuries)] / Gl. red. chl.-kor. AN SSSR R. I. Avanesov; V R. I. Avanesov, dfn I. S. Ulukhanov; XI dfn V. B. Krys'ko. Moscow, 1988-19891990-1991-2000-2002-2004-..-2012-2013-2016- — prodolzh. T. I-II-III-IV-VVI-VII-VIII-IX-X-XI - continued.

SIRYa XI-XVII vv. - Slovar' russkogo yazyka XI-XVII vv. [Dictionary of the Russian Language of the $11^{\text {th }}-17^{\text {th }}$ Centuries] Composed by: N. B. Bakhilina, G. A. Bogatova, E.N. Prokopovich et al. Editors in chief S. G. Barkhudarov, G. A. Bogatova et al. Iss. 1-30 - continued, Moscow, 1975-2015 - continued.

SIRYa XI-XVII vv. Sprav. Vyp. - Slovar' russkogo yazyka XI-XVII vv. Spravochnyi vypusk / In-t rus. yaz. im. V.V. Vinogradova RAN. — Moscow: Nauka Publ., 2001. — 814 p.

SIRYa XVIII v. - Slovar' russkogo yazyka XVIII veka [Dictionary of the Russian Language of the $18^{\text {th }}$ century]. Leningrad / St Petersburg: Nauka, 1984-2015-. Iss. 1-21(up to pomoshchnyi). 
SRNG - Slovar' russkikh narodnykh govorov [Dictionary of Russian Dialects] / Ed. by F.P. Filin, F.P. Sorokoletov, S. A. Myznikov. — Moscow, Leningrad, 1965-2017-. Iss. $1-50-$.

Turaŭski sl. / Kryvitski i dr. - Turaŭski sloŭnik [The Turovo Dictionary]. Compiled by A. A. Kryvitski, G. A. Tsykhun, I. Ya. Yashkin. 1-2 - . Minsk, 1982-.

Ushakov - Tolkovyi slovar' russkogo yazyka [Interpretative Dictionary of The Russian Language] / Ed by D. N. Ushakov: In 4 vols. Moscow, 1935-1940.

AfslPh - Archiv für slavische Philologie, begründet von V. Jagić [Archive for Slavic Philology, founded by V. Jagić], Berlin 1876-1929.

BB - Beiträge zur Kunde der Indogermanischen Sprachen [Contributions to the Study of Indo-European Languages]. Hrsg. A. Bezzenberger. 1-30 . Göttingen 1877-1906.

Boryś SEJP — Boryś W. Stownik etymologiczny języka polskiego [Etymological Dictionary of the Polish Language]. Kraków, 2005.

BSL - Bulletin de la Société de linguistique de Paris [Bulletin of the Linguistic Society of Paris].

Hujer // LF, 1933, LX, 473-474 - Hujer O. Mélanges de philologie offerts a M.J.J. Mikkola [Philological Miscellanea Offered to M.J.J. Mikkola] // Listy filologické [Philological Notes], 1933, 60, 472-474.

IF - Indogermanische Forschungen. Zeitschrift für Indogermanistik und allgemeine Sprachwissenschaft [Indo-European Research. Journal of Indo-European and General Linguistics]. Strassburg - Berlin.

Kralik SESS - Králik, L'ubor. Stručný etymologický slovník slovenčiny [A Concise Etymological Dictionary of Slovenian]. Bratislava: VEDA, 2015.

KZ - Zeitschrift für vergleichende Sprachforschung auf dem Gebiete der indogermanischen Sprachen [Journal for Comparative Language Studies in the Field of IndoEuropean Languages], founded by A. Kuhn. Berlin — Güttersloh — Göttingen 1852 -

LF — Listy filologické, Praha $1874 \mathrm{nn}$.

Machek ESJČaS - Machek V. Etymologický slovník jazyka českého a slovenského [Etymological Dictionary of Czech and Slovenian]. Praha, 1957.

Meillet // BSL 29 - Meillet, Antoine // Bulletin de la Société de linguistique de Paris [Bulletin of the Linguistic Society of Paris] n.29.

Meillet // IF 5 - Meillet, Antoine // Indogermanische Forschungen, Zeitschrift für Indogermanistik und allgemeine Sprachwissenschaft. Strassburg - Berlin. n. 5.

Meillet // MSL 8; 10 - Meillet, Antoine // Mémoires de la Société de linguistique de Paris [Memoirs of the Linguistic Society of Paris]. nn. 8, 10

Meillet // RS 3 - Meillet, Antoine // Rocznik Slawistyczny [Slavic Yearbook]. Wrocław - Kraków - Warszawa n. 3

Meillet EAM - Meillet, Antoine. Esquisse d'une grammaire comparée de l'arménien classique [A Sketch of a Comparative Grammar of Classical Armenian]. Paris, 1903.

Meillet Études. - Meillet, Antoine. Études sur l'étymologie et le vocabulaire du vieux slave, $I-I I$ [Studies on the Etymology and Vocabulary of Old Slavonic]. Paris, Bouillon. 1902, 1905. 
Mikkola // RS 1 - Mikkola J.J. // Rocznik Slawistyczny [Slavic Yearbook]. Wrocław - Kraków - Warszawa n 1.

Mikkola // BB 22 - Mikkola J.J. // Beiträge zur Kunde der Indogermanischen Sprachen. Hrsg. A. Bezzenberger. N 22 (1898). Göttingen.

Mikkola Urslav. Gramm. - Mikkola J.J. Urslavische Grammatik [Proto-Slavic Grammar]. 1. Teil. 1913, 2. Teil. 1942, 3. Teil. 1950, Heidelberg.

Mladenov St. Aind. ambhṛnás // KZ 44 - Mladenov St. Altindisches ambhṛnás (амфора) // Zeitschrift für vergleichende Sprachforschung auf dem Gebiete der indogermanischen Sprachen, begr. v. A. Kuhn. Berlin — Güttersloh — Göttingen, № 44, 1896.

MSL — Mémoires de la Société de linguistique de Paris [Memoirs of the Linguistic Society of Paris].

Pāṇini 6-4, 157 - Pāṇini's Grammatik [Pāṇini’s Grammar], edited by O. Böhtlingk, Leipzig, 1887.

Pedersen // KZ 38 - Pedersen H. // Zeitschrift für vergleichende Sprachforschung auf dem Gebiete der indogermanischen Sprachen, founed by A. Kuhn. Berlin - Güttersloh — Göttingen, XXXVIII, 1890-395.

Rejzek ČEJ - Rejzek J. Český etymologický slovník [Czech Etymological Dictionary]. Voznice, 2001.

RÉS - Revue des études slaves [Review of Slavic Studies], Paris, 1921-.

RS - Rocznik Slawistyczny [Slavic Yearbook]. Wrocław — Kraków - Warszawa.

Trautmann // AfslPh 38 - Trautmann R. // Archiv für slavische Philologie [Archive for Slavic Philology], founded by V. Jagić, Berlin XXXVIII, 1914, 130.

Trautmann Apr. Sprd. - Die Altpreußischen Sprachdenkmäler von R. Trautmann, t. 1-2, Göttingen, 1909-1910.

Trautmann BSW - Trautmann R. Baltisch-slavisches Wörterbuch [Baltic-Slavic Dictionary]. Göttingen, 1923.

Vaillant // RÉS XI - Vaillant A. // Revue des études slaves, Paris, XI, 1932: 206.

Watkins IER - The American Heritage' Dictionary of Indo-European Roots. 2nd Edition, revised and edited by Calvert Watkins. Boston, New York: Houghton Mifflin Company, 2000. 